\title{
Atorvastatin inhibits the immediate-early response gene EGR1 and improves the functional profile of CD4+T-Iymphocytes in acute coronary syndromes
}

\author{
Anna Severino ${ }^{1, *}$, Chiara Zara ${ }^{1, *}$, Mara Campioni ${ }^{1}$, Davide Flego ${ }^{1}$, Giulia Angelini ${ }^{1}$, \\ Daniela Pedicino ${ }^{1}$, Ada Francesca Giglio ${ }^{1}$, Francesco Trotta ${ }^{1}$, Simona Giubilato ${ }^{1}$, \\ Vincenzo Pazzano ${ }^{1}$, Claudia Lucci ${ }^{1}$, Antonio Iaconelli ${ }^{1}$, Aureliano Ruggio ${ }^{1}$, Luigi \\ Marzio Biasucci ${ }^{1}$, Filippo Crea ${ }^{1, * *}$ and Giovanna Liuzzo ${ }^{1, * *}$ \\ ${ }^{1}$ Institute of Cardiology, Catholic University, Rome, Italy \\ * These authors have contributed equally to this work \\ ** These authors have contributed equally to this work \\ Correspondence to: Giovanna Liuzzo, email: giovanna.liuzzo@gmail.com \\ Keywords: acute coronary syndromes; T-lymphocytes; transcription factors; statins; inflammation; Pathology Section \\ Received: December 08, $2016 \quad$ Accepted: February 07, 2017 \\ Published: February 16, 2017
}

\section{ABSTRACT}

Background- Adaptive immune-response is associated with a worse outcome in acute coronary syndromes. Statins have anti-inflammatory activity beyond lowering lipid levels. We investigated the effects of ex-vivo and in-vivo atorvastatin treatment in acute coronary syndromes on $\mathrm{CD4}^{+}{ }^{+} \mathrm{T}-$ cells, and the underlying molecular mechanisms.

Approach and results- Blood samples were collected from $\mathbf{5 0}$ statin-naïve acute coronary syndrome patients. We assessed $\mathrm{CD4}^{+} \mathrm{T}$-cell activation by flow-cytometry, the expression of $84 \mathrm{~T}$-helper transcription-factors and $84 \mathrm{~T}$-cell related genes by RTqPCR, and protein expression by Western-blot, before and after 24-hours incubation with increasing doses of atorvastatin: 3-10-26 $\mu \mathrm{g} / \mathrm{ml}$ (corresponding to blood levels achieved with doses of 10-40-80 $\mathrm{mg}$, respectively). After incubation, we found a significant decrease in interferon- $y-p r o d u c i n g ~ C D 4+C D 28^{\text {null }}$-cells $(P=0.009)$ and a significant increase in interleukin-10-producing CD4 ${ }^{+}$CD25 $5^{\text {hight }} \mathrm{T}$-cells $(P<0.001)$. Atorvastatin increased the expression of 2 genes and decreased the expression of 12 genes (in particular, EGR1, FOS,CCR2 and toll like receptor-4; >3-fold changes).

The in-vivo effects of atorvastatin were analyzed in 10 statin-free acute coronary syndrome patients at baseline, and after $24 \mathrm{~h}$ and $48 \mathrm{~h}$ of atorvastatin therapy ( 80 $\mathrm{mg} /$ daily): EGR1-gene expression decreased at $24 \mathrm{~h}(P=0.01)$ and $48 \mathrm{~h}(P=0.005)$; EGR1-protein levels decreased at $48 \mathrm{~h}(P=0.03)$.

Conclusions-In acute coronary syndromes, the effects of atorvastatin on immune system might be partially related to the inhibition of the master regulator gene EGR1. Our finding might offer a causal explanation on why statins improve the early outcome in acute coronary syndromes.

\section{INTRODUCTION}

Over the past few years our understanding of the importance of inflammation in coronary instability is considerably increased [1].

$\mathrm{CD} 4^{+} \mathrm{CD} 28^{\text {null }}$ T-cells are a subset of long-lived directly cytotoxic $\mathrm{CD}^{+} \mathrm{T}$-lymphocytes producing large amount of the pro-inflammatory cytokine interferon- $\gamma$ $(\mathrm{IFN}-\gamma)$, that have been implicated in the pathogenesis of various chronic inflammatory diseases. We previously demonstrated that circulating $\mathrm{CD} 4{ }^{+} \mathrm{CD} 28^{\text {null }}$ T-cell frequency higher than $4 \%$ increase the risk of acute coronary syndromes (ACS), particularly in diabetic patients $[2,3]$.

At the other extreme, naturally occurring regulatory T-cells are a major cellular source of interleukin (IL)-10, a potent anti-inflammatory cytokine. These regulatory T-cells are involved in the control of autoimmunity [4]. 
Table 1: Baseline characteristics of study population: 50 statin-naïve ACS patients.

\begin{tabular}{|l|c|}
\hline Age, mean \pm SD (years) & $64 \pm 12$ \\
\hline Sex, $\mathrm{n}(\mathrm{F} / \mathrm{M})$ & $10 / 40$ \\
\hline Clinical Presentation (UAIIB/NSTEMI) & $8 / 42$ \\
\hline Smokers, $\mathrm{n}(\%)$ & $29(58 \%)$ \\
\hline Family History of CAD, $\mathrm{n}(\%)$ & $19(38 \%)$ \\
\hline Hypertension, $\mathrm{n}(\%)$ & $33(66 \%)$ \\
\hline Obesity, $\mathrm{n}(\%)$ & $10(20 \%)$ \\
\hline Dyslipidemia, $\mathrm{n}(\%)$ & $26(52 \%)$ \\
\hline Previous Cardiovascular Events, $\mathrm{n}(\%)$ & $7(14 \%)$ \\
\hline Previous PCI/CABG, $\mathrm{n}(\%)$ & $10 / 5(20 \% / 10 \%)$ \\
\hline Multivessel disease, $\mathrm{n}(\%)$ & $23(46 \%)$ \\
\hline In-hospital PCI/CABG, $\mathrm{n}(\%)$ & $32 / 14(64 \% / 28 \%)$ \\
\hline LVEF, mean \pm SD $(\%)$ & $51 \pm 0.12$ \\
\hline Total-C, mean \pm SD $(\mathrm{mg} / \mathrm{dl})$ & $185.3 \pm 49.1$ \\
\hline LDL-C, mean \pm SD $(\mathrm{mg} / \mathrm{dl})$ & $130.9 \pm 34.3$ \\
\hline HDL-C, mean \pm SD $(\mathrm{mg} / \mathrm{dl})$ & $40.9 \pm 12.8$ \\
\hline TG, mean \pm SD $(\mathrm{mg} / \mathrm{dl})$ & $142.8 \pm 85.1$ \\
\hline Plasma glucose, mean \pm SD $(\mathrm{mg} / \mathrm{dl})$ & $114.2 \pm 39.1$ \\
\hline Lymphocytes, median-range (103/ml) & $1.65(0.63-4.33)$ \\
\hline
\end{tabular}

$\mathrm{ACS}=$ acute coronary syndromes; $\mathrm{UA}=$ unstable angina; NSTEMI=non-ST elevation acute myocardial infarction; $\mathrm{CAD}=$ coronary artery disease; $\mathrm{PCI}=$ percutaneous coronary intervention; $\mathrm{CABG}=$ coronary artery by-pass graft; $\mathrm{LVEF}=$ left ventricular ejection fraction; Total-C = Total-Cholesterol; LDL-C = LDL-Cholesterol; HDL-C = HDL-Cholesterol; $\mathrm{TG}=$ triglycerides.

Accordingly, a lower number or a decreased function of these cells has been found in patients suffering from lupus erythematous, type-1 diabetes, rheumatoid arthritis, and multiple sclerosis [5], as well as in patients with ACS $[6,7]$. Moreover, in ACS the production of proinflammatory cytokines is not adequately counterbalanced by anti-inflammatory cytokines, such as IL-10; these alterations have been related to a worse short- and longterm prognosis $[8,9]$. We recently observed that a subset of ACS patients presents an alteration of the immune response, associated to a worse outcome and characterized by reduced regulatory T-cell response to effector T-cell expansion [10].

Statins have anti-inflammatory and immunesuppressive activity besides lowering lipids that may, at least partially, account for their outcome improvement in the setting of both acute and chronic ischemic heart disease $[11,12,13]$. In particular, statins attenuate T-cell activation and proliferation, inhibit pro-inflammatory cytokine secretion and enhance anti-inflammatory cytokine secretion $[14,15,16]$. Two observational retrospective studies of our group have shown that in ACS the use of statins was associated with reduced levels of CD $4^{+} \mathrm{CD} 28^{\text {null }}$ T-cells $[17,2]$. In a small number of ACS patients, rosuvastatin treatment for 6 weeks induced $\mathrm{CD} 4^{+} \mathrm{CD} 28^{\text {null }}$ T-cell apoptosis [18]. Recent studies have also suggested that statins may enhance regulatory T-cell responses $[19,20,21]$.

In the present study, we sought to investigate the effects of increasing doses of atorvastatin on phenotype and function of different $\mathrm{CD} 4^{+} \mathrm{T}$-cell subsets, obtained from 50 statin-naïve patients presenting with non-ST elevation (NSTE)-ACS and raised levels of $\mathrm{CD} 4{ }^{+} \mathrm{CD} 28^{\text {null }} \mathrm{T}$-cells. To explore the mechanisms by which atorvastatin might suppress the immune response in ACS, we analyzed by quantitative PCR array the expression of 84 transcription factors involved in the immune response and 84 genes related to the functional properties of different T-helper cell subsets.

Finally, we assessed the in-vivo effects of high-dose of atorvastatin $(80 \mathrm{mg} /$ daily) in ACS patients.

\section{RESULTS}

Patient selection and study design are presented in Figure-1.

Table 1 summarizes the clinical characteristics of the study population.

The percentage of total CD4 ${ }^{+} \mathrm{T}$-cells, $\mathrm{CD} 4^{+} \mathrm{CD} 28^{\text {null }} \mathrm{T}$ cells, CD $4^{+} \mathrm{CD} 25^{\text {high }} \mathrm{T}$-cells and $\mathrm{CD} 4{ }^{+} \mathrm{CD} 25^{\text {high }} \mathrm{T}$-cells expressing the transcription factor Foxp3 did not change significantly after $e x$-vivo treatment with increasing doses of atorvastatin for 24 hours (Figure 2).

\section{Effects of atorvastatin on $\mathrm{CD}^{+} \mathrm{CD} 28^{\text {null }}$ T-cells and $\mathrm{CD}^{+} \mathrm{CD}^{2} 5^{\text {high }} \mathrm{T}$-cells}

The activation of $\mathrm{CD} 4^{+} \mathrm{CD} 28^{\text {null }}$ T-cells and $\mathrm{CD} 4^{+} \mathrm{CD} 25^{\text {hight }}$-cell subset was modified by atorvastatin 
treatment. Indeed, the percentage of $\mathrm{CD} 4{ }^{+} \mathrm{CD} 28^{\text {null }} \mathrm{T}$-cells producing IFN- $\gamma$ decreased from a median of $44.1 \%$ (range 20.5-60.9) (untreated cells) to $15.0 \%$ (range 8.623.8) after incubation with $26 \mu \mathrm{g} / \mathrm{ml}$ of atorvastatin ( $P$ for trend $=0.009$ ) (Figure-3). Conversely, the percentage of $\mathrm{CD} 4{ }^{+} \mathrm{CD} 25^{\text {high }}$ T-cells producing IL-10 increased from a median of $38.6 \%$ (range 13.5-67.1) (untreated cells) to $71.1 \%$ (range 44.3-95.5), after incubation with $26 \mu \mathrm{g} / \mathrm{ml}$ of atorvastatin ( $\mathrm{P}$ for trend $<0.001$ ). Accordingly, the MFI of intracellular IL-10 expression increased after treatment (from $24.4 \pm 13.5$ to $53.3 \pm 22.3$; $\mathrm{P}$ for trend $<0.001$ ) (Figure-4, panel A-B).

\section{Effects of atorvastatin on pro-inflammatory and} anti-inflammatory cytokine concentrations

IL-10 concentration increased from a median of $1.5 \mathrm{pg} / \mathrm{mL}$, range $0.7-39.9$ (untreated blood) to $6.3 \mathrm{pg} / \mathrm{mL}$ (range 1-42.7) after incubation of whole blood samples, collected from an antecubital vein at the time of patient enrollment, with $26 \mu \mathrm{g} / \mathrm{ml}$ of atorvastatin (P for trend $=$ 0.024) (Figure-4, Panel C). Although we used a highsensitivity ELISA kit, IFN- $\gamma$ was detectable in few patients at baseline and resulted undetectable after atorvastatin treatment (data not shown).

Atorvastatin decreases the expression of key cellular pathways in ACS CD4 ${ }^{+}$T-cells

To identify mechanisms by which atorvastatin might have immune-suppressive effects in CD4+T-cell populations, we analyzed the gene expression of a focused panel of 84 transcription factors downstream of signaling from cytokines, chemokines, growth factors, androgens and Toll-Like receptors. Then, we performed a PCR array profiling the expression of 84 genes including cytokine genes representative of the three classes of helper T-cells, genes encoding transcriptional factors that regulate the expression of these cytokines, markers of CD4+T-cell activation and other genes involved in the adaptive

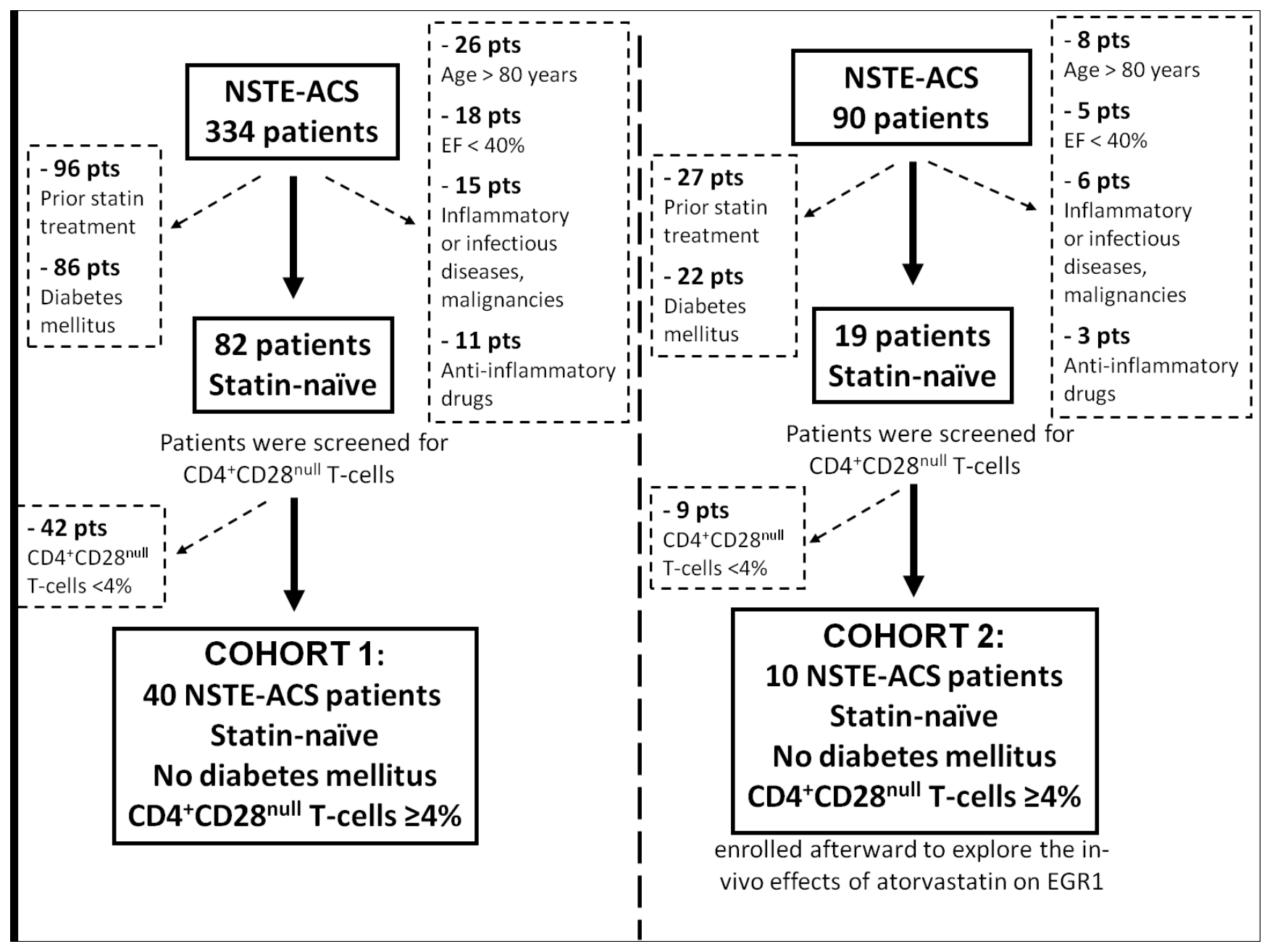

Figure 1: Flow diagram of patient selection and study design. NST-ACS $=$ Non ST elevation acute coronary syndrome; EF $=$ left ventricular ejection fraction. 
immune responses. PCR array analysis was applied on pooled RNA samples.

The complete list of genes investigated by PCR arrays, and their different expression after atorvastatin treatment, is reported in Table- 2 and 3.
PCR array analysis revealed that the expression of 2 genes was increased while the expression of 12 genes was decreased ( $>3$-fold changes) by ex-vivo treatment of freshly isolated $\mathrm{CD} 4^{+} \mathrm{T}$-cells from ACS patients with a dose of $26 \mu \mathrm{g} / \mathrm{ml}$ atorvastatin for 24 hours compared

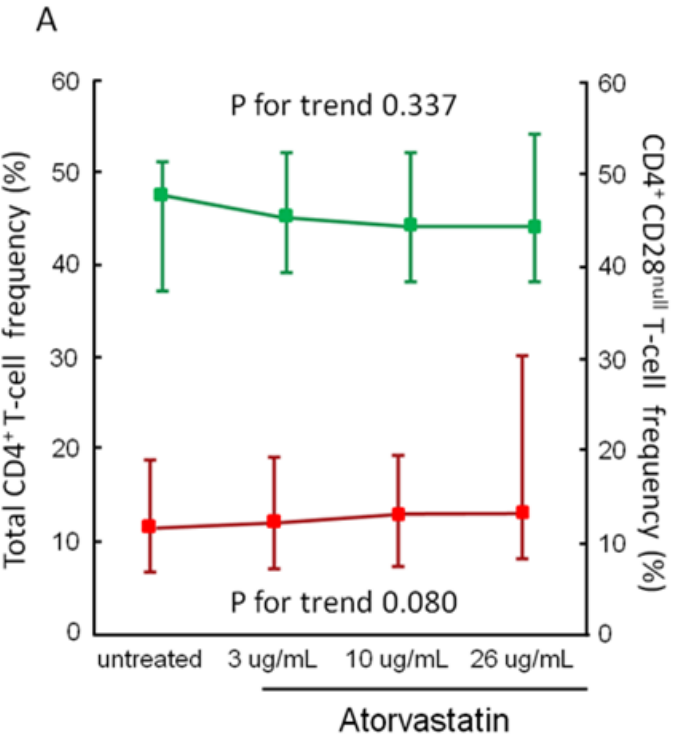

Atorvastatin

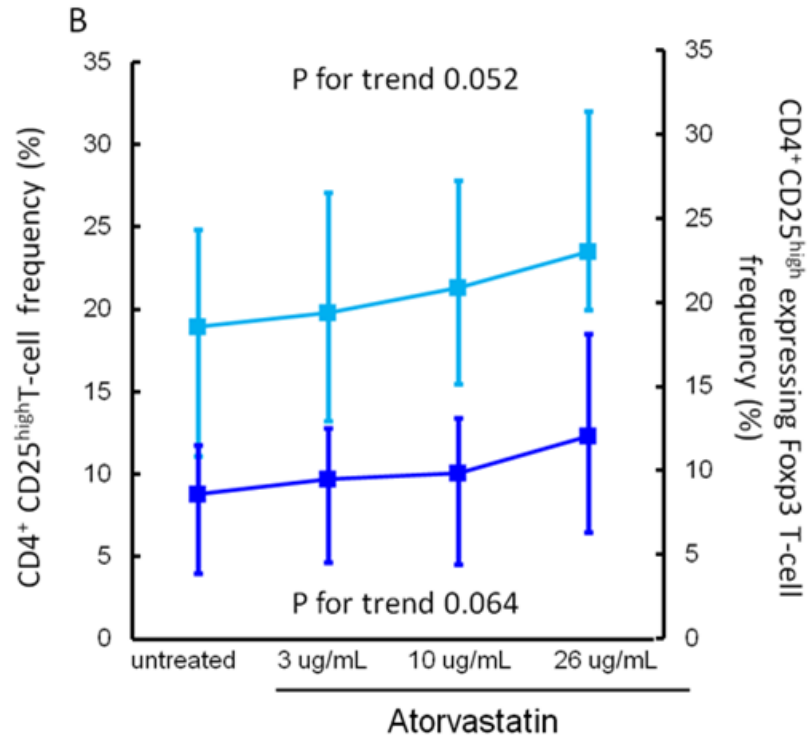

$R=0.67 ; P<0.001$

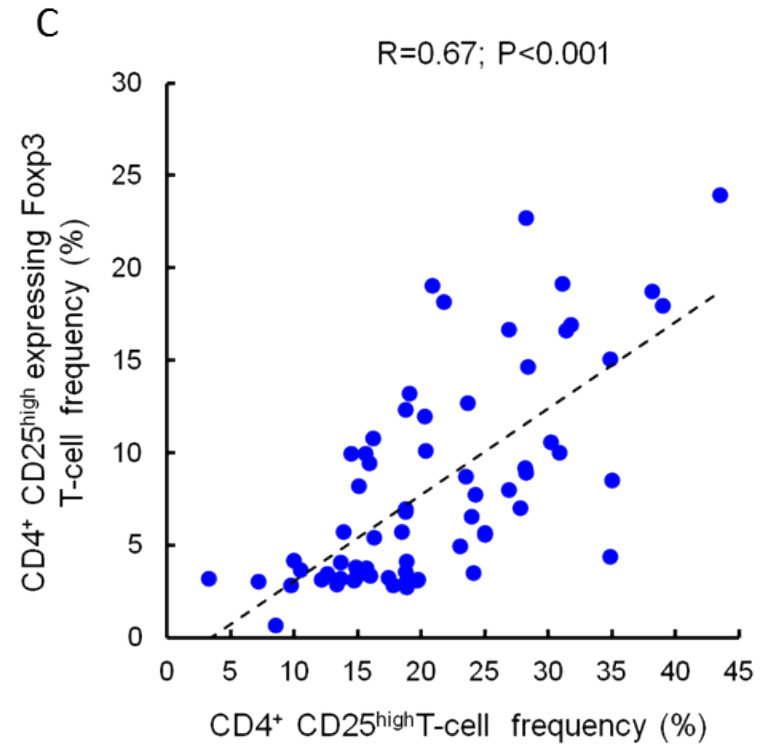

Figure 2: Effects of atorvastatin on total $\mathrm{CD4}^{+} \mathrm{T}$-cells, $\mathrm{CD4}{ }^{+} \mathrm{CD28}{ }^{\text {null }}$ T-cells, $\mathrm{CD}^{+} \mathrm{CD25}{ }^{\text {high }} \mathrm{T}^{-c e l l s}$ and $\mathrm{CD}^{+} \mathrm{CD25}{ }^{\text {high }}$ Foxp3 ${ }^{+}$T-cells. Panel A. Frequencies of total $\mathrm{CD} 4^{+}$and of $\mathrm{CD} 4^{+} \mathrm{CD} 28^{\text {null }}$ T-cells were determined by flow-cytometry. CD4 ${ }^{+} \mathrm{T}$-cells were isolated from peripheral blood samples of 20 statin-naïve NST-ACS patients and incubated for 24 hours without and with increasing doses of atorvastatin. Data are presented as median and 95\% CI. The percentage of both total $\mathrm{CD}^{+}$(indicated in green) and of CD4 $4^{+} \mathrm{CD} 28^{\text {null }}$ T-cells (indicated in red) did not change significantly after treatment with atorvastatin ( $\mathrm{P}$ for trend $=0.337$ and 0.080 , respectively). Panel B. Frequencies of $\mathrm{CD} 4{ }^{+} \mathrm{CD} 25^{\text {high }} \mathrm{T}$-cells and of $\mathrm{CD} 4{ }^{+} \mathrm{CD} 25^{\text {high }} \mathrm{T}$-cells expressing the transcription factor Foxp3 were determined as described in Panel A. Data are presented as median and 95\% CI. The percentage of both total CD4 $4^{+}$D $25^{\text {high }}$-cells (indicated in light blue) and of $\mathrm{CD}^{+} \mathrm{CD} 25^{\text {high }}$ Foxp3 $3^{+}$T-cells (indicated in dark blue) showed slight, but not statistically significant, changes after treatment with atorvastatin ( $\mathrm{P}$ for trend $=0.052$ and 0.064 , respectively). Panel C. Correlation between $\mathrm{CD} 4{ }^{+} \mathrm{CD} 25^{\text {high }} \mathrm{T}-\mathrm{cells}$ and $\mathrm{CD} 4{ }^{+} \mathrm{CD} 25^{\text {high }}$ Foxp $3^{+} \mathrm{T}$-cells. Frequencies of $\mathrm{CD} 4{ }^{+} \mathrm{CD} 25^{\text {high }} \mathrm{T}$-cells and of $\mathrm{CD} 4^{+} \mathrm{CD} 25^{\text {high }} \mathrm{T}$-cells expressing the transcription factor Foxp3 were calculated as percentage of $\mathrm{CD}^{+} \mathrm{CD} 25^{+} \mathrm{T}$-cell population. A significant correlation was observed among these T-cell subsets $(\mathrm{R}=0.67 ; P<0.001)$. Spearman rank correlation was performed on pooled data (untreated/treated with increased doses of atorvastatin). 
Table 2: Genes investigated by Human Transcription Factors RT $^{2}$ Profiler $^{\mathrm{TM}}$ PCR Array, and changes in their expression induced by atorvastatin.

\begin{tabular}{|c|c|c|c|}
\hline Position & Symbol & Description & Fold Regulation \\
\hline A01 & AR & Androgen receptor & 3,6217 \\
\hline A02 & ARNT & Aryl hydrocarbon receptor nuclear translocator & 2,5198 \\
\hline A03 & ATF1 & Activating transcription factor 1 & $-1,3044$ \\
\hline A04 & ATF2 & Activating transcription factor 2 & $-1,1277$ \\
\hline A05 & ATF3 & Activating transcription factor 3 & 1,0473 \\
\hline A06 & ATF4 & $\begin{array}{l}\text { Activating transcription factor } 4 \\
\text { (tax-responsive enhancer element B67) }\end{array}$ & 1,0329 \\
\hline A07 & CEBPA & CCAAT/enhancer binding protein (C/EBP), alpha & $-2,7959$ \\
\hline A08 & СЕВРВ & CCAAT/enhancer binding protein (C/EBP), beta & $-1,4077$ \\
\hline A09 & CEBPG & CCAAT/enhancer binding protein (C/EBP), gamma & $-1,4880$ \\
\hline A10 & CREB1 & CAMP responsive element binding protein 1 & $-1,1277$ \\
\hline A11 & CREBBP & CREB binding protein & $-1,3226$ \\
\hline A12 & CTNNB1 & Catenin (cadherin-associated protein), beta $1,88 \mathrm{kDa}$ & $-1,6058$ \\
\hline B01 & DR1 & Down-regulator of transcription 1, TBP-binding (negative cofactor 2) & $-2,3027$ \\
\hline B02 & E2F1 & E2F transcription factor 1 & 1,2454 \\
\hline B03 & E2F6 & E2F transcription factor 6 & $-1,4777$ \\
\hline B04 & EGR1 & Early growth response 1 & $-10,9710$ \\
\hline B05 & ELK1 & ELK1, member of ETS oncogene family & $-1,0743$ \\
\hline B06 & ESR1 & Estrogen receptor 1 & $-1,1674$ \\
\hline B07 & ETS1 & V-ets erythroblastosis virus E26 oncogene homolog 1 (avian) & $-1,5837$ \\
\hline B08 & ETS2 & V-Ets erythroblastosis virus E26 oncogene homolog 2 (avian) & $-1,2340$ \\
\hline B09 & FOS & FBJ murine osteosarcoma viral oncogene homolog & $-5,5533$ \\
\hline B10 & FOXA2 & Forkhead box A2 & 2,5198 \\
\hline B11 & FOXO1 & Forkhead box O1 & $-1,3044$ \\
\hline B12 & GATA1 & GATA binding protein 1 (globin transcription factor 1 ) & $-1,9498$ \\
\hline $\mathrm{C} 01$ & GATA2 & GATA binding protein 2 & 1,0842 \\
\hline $\mathrm{C} 02$ & GATA3 & GATA binding protein 3 & $-1,4777$ \\
\hline $\mathrm{C} 03$ & GTF2B & General transcription factor IIB & $-1,2340$ \\
\hline $\mathrm{C} 04$ & GTF2F1 & General transcription factor IIF, polypeptide $1,74 \mathrm{kDa}$ & $-1,2599$ \\
\hline $\mathrm{C} 05$ & HAND1 & Heart and neural crest derivatives expressed 1 & 1,4506 \\
\hline $\mathrm{C} 06$ & HAND2 & Heart and neural crest derivatives expressed 2 & 2,4566 \\
\hline $\mathrm{C} 07$ & HDAC1 & Histone deacetylase 1 & 1,0918 \\
\hline $\mathrm{C} 08$ & HIF1A & Hypoxia inducible factor 1, alpha subunit (basic helix-loop-helix transcription factor) & $-1,2426$ \\
\hline $\mathrm{C} 09$ & HNF4A & Hepatocyte nuclear factor 4 , alpha & 1,0842 \\
\hline $\mathrm{C} 10$ & HOXA5 & Homeobox A5 & 1,0842 \\
\hline $\mathrm{C} 11$ & HSF1 & Heat shock transcription factor 1 & 1,0918 \\
\hline $\mathrm{C} 12$ & ID1 & Inhibitor of DNA binding 1, dominant negative helix-loop-helix protein & $-2,0326$ \\
\hline D01 & IRF1 & Interferon regulatory factor 1 & 1,0693 \\
\hline D02 & JUN & Jun proto-oncogene & 2,5198 \\
\hline D03 & JUNB & Jun B proto-oncogene & $-1,3883$ \\
\hline D04 & JUND & Jun D proto-oncogene & $-1,1045$ \\
\hline D05 & MAX & MYC associated factor $\mathrm{X}$ & $-1,1514$ \\
\hline D06 & MEF2A & Myocyte enhancer factor 2A & $-1,2426$ \\
\hline
\end{tabular}




\begin{tabular}{|c|c|c|c|}
\hline D07 & MEF2B & Myocyte enhancer factor 2B & $-1,4473$ \\
\hline D08 & MEF2C & Myocyte enhancer factor $2 \mathrm{C}$ & 2,9214 \\
\hline D09 & MYB & V-myb myeloblastosis viral oncogene homolog (avian) & 1,0116 \\
\hline D10 & MYC & V-myc myelocytomatosis viral oncogene homolog (avian) & $-1,0595$ \\
\hline D11 & MYF5 & Myogenic factor 5 & 1,0842 \\
\hline D12 & MYOD1 & Myogenic differentiation 1 & 1,0842 \\
\hline E01 & NFAT5 & Nuclear factor of activated T-cells 5 , tonicity-responsive & $-1,2255$ \\
\hline E02 & NFATC1 & Nuclear factor of activated T-cells, cytoplasmic, calcineurin-dependent 1 & $-1,4777$ \\
\hline E03 & NFATC2 & Nuclear factor of activated T-cells, cytoplasmic, calcineurin-dependent 2 & $-1,0595$ \\
\hline E04 & NFATC3 & Nuclear factor of activated T-cells, cytoplasmic, calcineurin-dependent 3 & $-1,2775$ \\
\hline E05 & NFATC4 & Nuclear factor of activated T-cells, cytoplasmic, calcineurin-dependent 4 & $-1,0892$ \\
\hline E06 & NFKB1 & Nuclear factor of kappa light polypeptide gene enhancer in B-cells 1 & 1,2283 \\
\hline E07 & NFYB & Nuclear transcription factor $Y$, beta & $-1,0595$ \\
\hline E08 & NR3C1 & Nuclear receptor subfamily 3 , group C, member 1 (glucocorticoid receptor) & $-1,1674$ \\
\hline E09 & PAX6 & Paired box 6 & 1,0046 \\
\hline E10 & POU2AF1 & POU class 2 associating factor 1 & $-3,3714$ \\
\hline E11 & PPARA & Peroxisome proliferator-activated receptor alpha & $-1,0305$ \\
\hline E12 & PPARG & Peroxisome proliferator-activated receptor gamma & 1,2805 \\
\hline F01 & RB1 & Retinoblastoma 1 & $-1,2512$ \\
\hline F02 & REL & V-rel reticuloendotheliosis viral oncogene homolog (avian) & $-1,4777$ \\
\hline F03 & RELA & V-rel reticuloendotheliosis viral oncogene homolog A (avian) & $-1,0449$ \\
\hline F04 & RELB & V-rel reticuloendotheliosis viral oncogene homolog B & 1,2030 \\
\hline F05 & SMAD1 & SMAD family member 1 & $-1,4880$ \\
\hline F06 & SMAD4 & SMAD family member 4 & $-1,0234$ \\
\hline F07 & SMAD5 & SMAD family member 5 & 1,2114 \\
\hline F08 & SMAD9 & SMAD family member 9 & $-1,1277$ \\
\hline F09 & SP1 & Sp1 transcription factor & $-1,2170$ \\
\hline F10 & SP3 & $\mathrm{Sp} 3$ transcription factor & $-1,0595$ \\
\hline F11 & STAT1 & Signal transducer and activator of transcription $1,91 \mathrm{kDa}$ & 1,0046 \\
\hline F12 & STAT2 & Signal transducer and activator of transcription $2,113 \mathrm{kDa}$ & $-1,2864$ \\
\hline G01 & STAT3 & Signal transducer and activator of transcription 3 (acute-phase response factor) & $-3,1748$ \\
\hline G02 & STAT4 & Signal transducer and activator of transcription 4 & $-1,0595$ \\
\hline G03 & STAT5A & Signal transducer and activator of transcription $5 \mathrm{~A}$ & $-1,2086$ \\
\hline G04 & STAT5B & Signal transducer and activator of transcription $5 \mathrm{~B}$ & 2,5198 \\
\hline G05 & STAT6 & Signal transducer and activator of transcription 6 , interleukin- 4 induced & 1,0257 \\
\hline G06 & TBP & TATA box binding protein & $-1,1755$ \\
\hline G07 & HNF1A & HNF1 homeobox A & 1,0842 \\
\hline G08 & TCF7L2 & Transcription factor 7-like 2 (T-cell specific, HMG-box) & 1,0842 \\
\hline G09 & TFAP2A & Transcription factor AP-2 alpha (activating enhancer binding protein 2 alpha) & 2,4061 \\
\hline G10 & TGIF1 & TGFB-induced factor homeobox 1 & 1,0473 \\
\hline G11 & TP53 & Tumor protein p53 & 1,0046 \\
\hline G12 & YY1 & YY1 transcription factor & $-1,2426$ \\
\hline
\end{tabular}

For each condition (untreated/treated with atorvastatin) a pool of RNA was constituted, starting with the same amount of RNA (500 ng) from each patient of Cohort 1 (see Methods).

Data are presented as fold of changes in gene expression induced by atorvastatin treatment as compared with the gene expression in untreated $\mathrm{CD} 4^{+} \mathrm{T}$-cells. Increased genes are indicated in red and decreased genes in green. A fold change in gene expression of $\geq 3$ was taken as significant. 
Table 3: Genes investigated by Human Th1-Th2-Th3 RT $^{2}$ Profiler $^{\text {TM }}$ PCR Array, and changes in their expression induced by atorvastatin.

\begin{tabular}{|c|c|c|c|}
\hline Position & Symbol & Description & Fold Regulation \\
\hline $\mathrm{A} 01$ & IL17A & Interleukin $17 \mathrm{~A}$ & $-1,0822$ \\
\hline A02 & CCL11 & Chemokine (C-C motif) ligand 11 & 1,0622 \\
\hline $\mathrm{A} 03$ & CCL5 & Chemokine (C-C motif) ligand 5 & $-1,1696$ \\
\hline A04 & CCL7 & Chemokine (C-C motif) ligand 7 & 1,0822 \\
\hline A05 & CCR2 & Chemokine (C-C motif) receptor 2 & $-3,4822$ \\
\hline A06 & CCR3 & Chemokine (C-C motif) receptor 3 & 2,5974 \\
\hline A07 & CCR4 & Chemokine (C-C motif) receptor 4 & 1,0310 \\
\hline A08 & CCR5 & Chemokine (C-C motif) receptor 5 & $-1,6656$ \\
\hline A09 & CD28 & CD28 molecule & $-1,1859$ \\
\hline A10 & CD4 & CD4 molecule & $-2,0648$ \\
\hline A11 & CD40LG & CD40 ligand & $-2,6500$ \\
\hline A12 & IL23A & Interleukin 23, alpha subunit p19 & $-1,4804$ \\
\hline B01 & CD80 & CD80 molecule & 1,0098 \\
\hline B02 & CD86 & CD86 molecule & $-7,4436$ \\
\hline B03 & СЕВPB & CCAAT/enhancer binding protein (C/EBP), beta & $-1,2025$ \\
\hline B04 & CREBBP & CREB binding protein & 1,0973 \\
\hline B05 & CSF2 & Colony stimulating factor 2 (granulocyte-macrophage) & 1,0822 \\
\hline B06 & CTLA4 & Cytotoxic T-lymphocyte-associated protein 4 & 1,0381 \\
\hline B07 & CXCR3 & Chemokine (C-X-C motif) receptor 3 & $-1,1065$ \\
\hline B08 & FASLG & Fas ligand (TNF superfamily, member 6) & $-1,5648$ \\
\hline B09 & GATA3 & GATA binding protein 3 & $-1,2710$ \\
\hline B10 & GFI1 & Growth factor independent 1 transcription repressor & $-1,3250$ \\
\hline B11 & GLMN & Glomulin, FKBP associated protein & $-1,5433$ \\
\hline B12 & GPR44 & G protein-coupled receptor 44 & $-1,9807$ \\
\hline $\mathrm{C} 01$ & HAVCR2 & Hepatitis A virus cellular receptor 2 & $-1,7484$ \\
\hline $\mathrm{C} 02$ & ICOS & Inducible T-cell co-stimulator & $-1,2277$ \\
\hline $\mathrm{C} 03$ & IFNG & Interferon, gamma & $-1,7487$ \\
\hline $\mathrm{C} 04$ & IGSF6 & Immunoglobulin superfamily, member 6 & $-2,2439$ \\
\hline $\mathrm{C} 05$ & IL10 & Interleukin 10 & 1,9411 \\
\hline $\mathrm{C} 06$ & IL12B & Interleukin 12B (natural killer cell stimulatory factor 2, cytotoxic lymphocyte maturation factor 2, p40) & $-1,1859$ \\
\hline $\mathrm{C} 07$ & IL12RB2 & Interleukin 12 receptor, beta 2 & $-1,1519$ \\
\hline $\mathrm{C} 08$ & IL13 & Interleukin 13 & $-1,0396$ \\
\hline C09 & IL13RA1 & Interleukin 13 receptor, alpha 1 & $-3,6200$ \\
\hline $\mathrm{C} 10$ & IL15 & Interleukin 15 & $-1,6313$ \\
\hline C11 & IL18 & Interleukin 18 (interferon-gamma-inducing factor) & $-5,8401$ \\
\hline $\mathrm{C} 12$ & IL18R1 & Interleukin 18 receptor 1 & $-1,1696$ \\
\hline D01 & IL1R1 & Interleukin 1 receptor, type I & $-1,1455$ \\
\hline D02 & IL1R2 & Interleukin 1 receptor, type II & 1,2693 \\
\hline D03 & IL2 & Interleukin 2 & $-2,3554$ \\
\hline D04 & IL2RA & Interleukin 2 receptor, alpha & $-1,4702$ \\
\hline D05 & IL4 & Interleukin 4 & 1,0822 \\
\hline D06 & IL4R & Interleukin 4 receptor & $-1,2108$ \\
\hline D07 & IL5 & Interleukin 5 (colony-stimulating factor, eosinophil) & $-1,7243$ \\
\hline
\end{tabular}




\begin{tabular}{|c|c|c|c|}
\hline D08 & IL6 & Interleukin 6 (interferon, beta 2) & $-5,9628$ \\
\hline D09 & IL6R & Interleukin 6 receptor & $-1,2277$ \\
\hline D10 & IL7 & Interleukin 7 & $-1,3159$ \\
\hline D11 & IL9 & Interleukin 9 & 1,0822 \\
\hline D12 & INHA & Inhibin, alpha & 1,0822 \\
\hline E01 & INHBA & Inhibin, beta A & 1,4682 \\
\hline E02 & IRF1 & Interferon regulatory factor 1 & 1,1761 \\
\hline E03 & IRF4 & Interferon regulatory factor 4 & $-1,0324$ \\
\hline E04 & JAK1 & Janus kinase 1 & $-1,0324$ \\
\hline E05 & JAK2 & Janus kinase 2 & $-1,0614$ \\
\hline E06 & LAG3 & Lymphocyte-activation gene 3 & $-1,4103$ \\
\hline E07 & LAT & Linker for activation of $\mathrm{T}$ cells & 1,0238 \\
\hline E08 & MAF & V-maf musculoaponeurotic fibrosarcoma oncogene homolog (avian) & $-1,0468$ \\
\hline E09 & MAP2K7 & Mitogen-activated protein kinase kinase 7 & $-1,1942$ \\
\hline E10 & MAPK8 & Mitogen-activated protein kinase 8 & 1,0028 \\
\hline E11 & NFATC1 & Nuclear factor of activated T-cells, cytoplasmic, calcineurin-dependent 1 & $-1,3159$ \\
\hline E12 & NFATC2 & Nuclear factor of activated T-cells, cytoplasmic, calcineurin-dependent 2 & $-1,0468$ \\
\hline F01 & NFATC2IP & Nuclear factor of activated T-cells, cytoplasmic, calcineurin-dependent 2 interacting protein & $-1,2799$ \\
\hline F02 & PCGF2 & Polycomb group ring finger 2 & $-1,7005$ \\
\hline F03 & PTPRC & Protein tyrosine phosphatase, receptor type, $\mathrm{C}$ & $-1,1696$ \\
\hline F04 & SFTPD & Surfactant protein D & 3,1037 \\
\hline F05 & SOCS1 & Suppressor of cytokine signaling 1 & 1,0098 \\
\hline F06 & SOCS2 & Suppressor of cytokine signaling 2 & $-1,5977$ \\
\hline F07 & SOCS5 & Suppressor of cytokine signaling 5 & 1,0747 \\
\hline F08 & SPP1 & Secreted phosphoprotein 1 & $-5,2634$ \\
\hline F09 & STAT1 & Signal transducer and activator of transcription $1,91 \mathrm{kDa}$ & 1,0673 \\
\hline F10 & STAT4 & Signal transducer and activator of transcription 4 & $-1,0973$ \\
\hline F11 & STAT6 & Signal transducer and activator of transcription 6 , interleukin- 4 induced & 1,0028 \\
\hline F12 & TBX21 & T-box 21 & $-1,0913$ \\
\hline G01 & TFCP2 & Transcription factor $\mathrm{CP} 2$ & $-1,3813$ \\
\hline G02 & TGFB3 & Transforming growth factor, beta 3 & 1,1127 \\
\hline G03 & TLR4 & Toll-like receptor 4 & $-3,4822$ \\
\hline G04 & TLR6 & Toll-like receptor 6 & $-1,4702$ \\
\hline G05 & TMED1 & Transmembrane emp24 protein transport domain containing 1 & $-1,4499$ \\
\hline G06 & TNF & Tumor necrosis factor & 1,0973 \\
\hline G07 & $\mathrm{CD} 27$ & CD27 molecule & $-1,2025$ \\
\hline G08 & TNFRSF8 & Tumor necrosis factor receptor superfamily, member 8 & $-5,4869$ \\
\hline G09 & TNFRSF9 & Tumor necrosis factor receptor superfamily, member 9 & $-1,5757$ \\
\hline G10 & TNFSF4 & Tumor necrosis factor (ligand) superfamily, member 4 & 1,0098 \\
\hline G11 & TYK2 & Tyrosine kinase 2 & $-1,1535$ \\
\hline G12 & YY1 & YY1 transcription factor & $-1,3909$ \\
\hline
\end{tabular}

For each condition (untreated/treated with atorvastatin) a pool of RNA was constituted, starting with the same amount of RNA $(500 \mathrm{ng})$ from each patient of Cohort 1 (see Methods).

Data are presented as fold of changes in gene expression induced by atorvastatin treatment as compared with the gene expression in untreated CD4+T-cells. Increased genes are indicated in red and decreased genes in green. A fold change in gene expression of $\geq 3$ was taken as significant. 
with control (Figure-5). Among the transcription factors, atorvastatin decreased the expression of early growth response 1 (EGR1) and V-fos FBJ murine osteosarcoma viral oncogene homolog (FOS). Among the genes related to helper T-cell pathway, atorvastatin decreased the expression of chemokine (C-C motif) receptor-2 (CCR2), the Toll-like receptor-4 (TLR4), and the proinflammatory cytokines IL-6 and IL-18.

To validate the PCR array results for selected genes, RT-qPCR was performed using RNA of each single patient. This set of data confirmed that atorvastatin significantly decreased the expression of CCR2 and of TLR4 as well as the expression of the transcription factors EGR1, FOS (Figure-6).

We also explored whether atorvastatin treatment might decrease EGR1 protein expression levels, as EGR1 gene showed the highest inhibition at PCR array analysis and also because EGR1 is a transcription factors critically involved in the immune response. Western-blot assay confirmed that incubation with atorvastatin $(26 \mu \mathrm{g} / \mathrm{ml})$ resulted in a significant reduction of EGR1 protein levels (from 5.0 \pm 2.6 to $1.9 \pm 0.97 ; P=0.038$ ) (Figure-7).

\section{In vivo effects of Atorvastatin}

The in-vivo effects of atorvastatin were analyzed in 10 statin-free ACS patients at baseline, and after 24 hours and 48 hours of atorvastatin therapy ( $80 \mathrm{mg} /$ daily). A

A

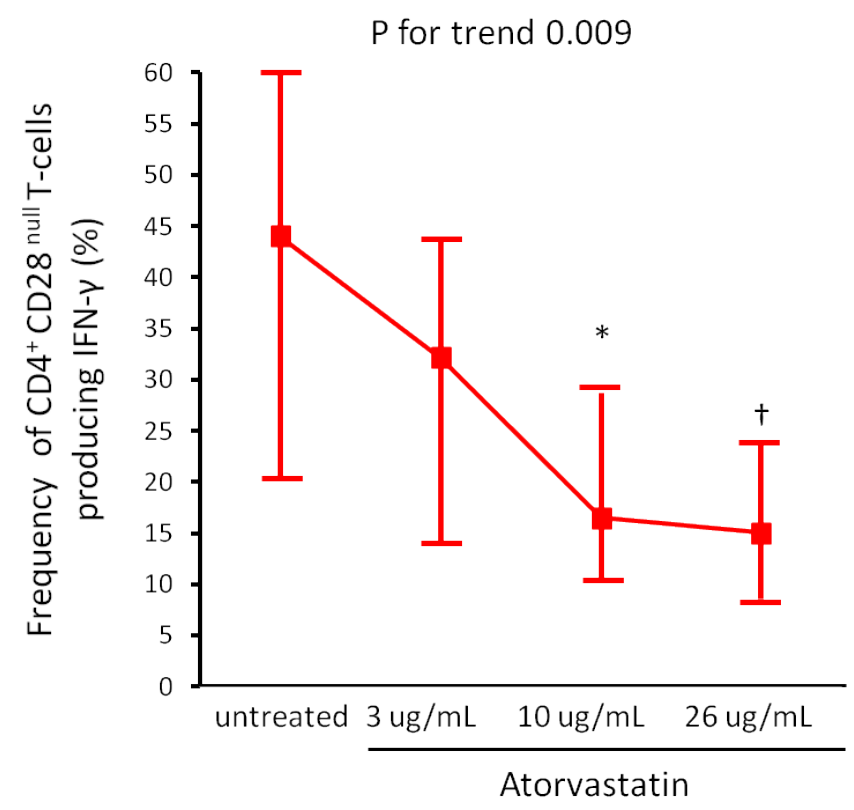

single high-dose of atorvastatin has early effects on EGR1 mRNA expression and, with a reasonable delay, on EGR1 protein levels. In all patients, EGR1 gene expression was reduced after $24 \mathrm{~h}$ of atorvastin therapy, from a mean $( \pm$ SEM) value of $26.7 \pm 5.7$ at baseline to $8.5 \pm 1.9$ at 24 hours $(P=0.01$ versus baseline $)$ and to $5.9 \pm 2.1$ at 48 hours ( $P=0.005$ versus baseline). Accordingly, EGR1 protein levels were significantly reduced after $48 \mathrm{~h}$ of atorvastatin treatment, from a mean ( \pm SEM) value of $26.1 \pm 2.2$ at baseline to $24.7 \pm 1.9$ at 24 hours $(P=0.67)$ and to $18.8 \pm 1.2$ at 48 hours ( $P=0.03$ versus baseline) (Figure 8$)$.

The mean fluorescence intensity of intracellular IFN- $\gamma$ expression by $\mathrm{CD} 4{ }^{+} \mathrm{CD} 28^{\text {null }}$ T-cells significantly decreased after 48hours of atorvastatin therapy (from $40.6 \pm 5.7$ to $30.9 \pm 4.0$ mean \pm S.E.M; P for trend $=0.0034$ ). Moreover, the mean fluorescence intensity of intracellular IL-10 expression by $\mathrm{CD} 4^{+} \mathrm{CD} 25^{\text {high }} \mathrm{T}$-cells significantly increased after 48hours of atorvastatin therapy (from $21.5 \pm 2.3$ to $40.7 \pm 7.1$; P for trend $<0.001$ ). Accordingly, the ratio between IL-10 and INF- $\gamma$ expression significantly increased (from $0.59 \pm 0.08$ to $1.78 \pm 0.64$; $\mathrm{P}$ for trend $=$ 0.002) (Figure 9).

\section{DISCUSSION}

In the present study, we observed that atorvastatin ex-vivo, at concentrations corresponding to blood levels achieved with 10-40-80 mg/die, and after short-time (24

B

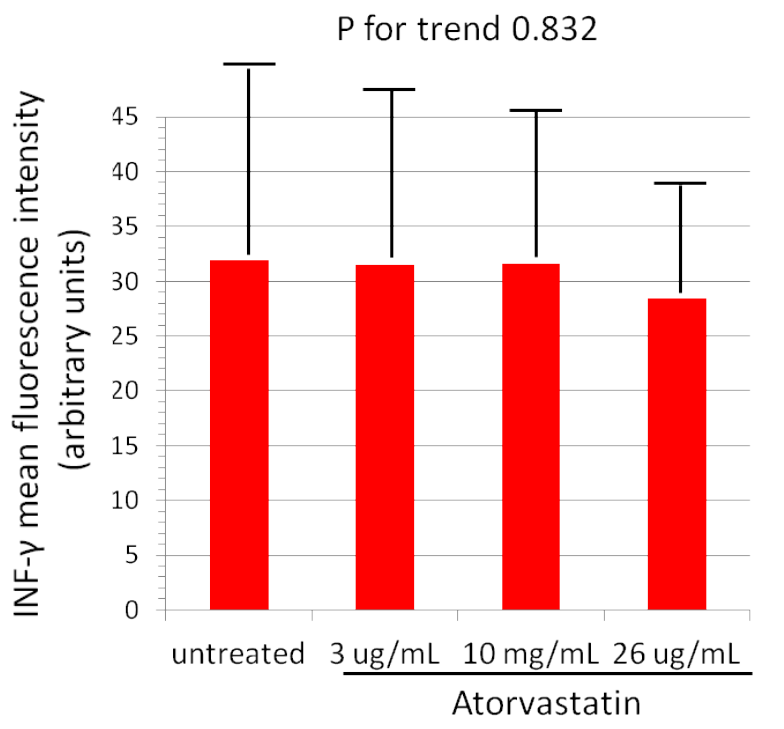

Figure 3: Effects of atorvastatin on $\mathrm{CD}^{+} \mathbf{C D 2 8} 8^{\text {null }}$ T-cells. CD4 ${ }^{+} \mathrm{T}$-cells were isolated from whole blood samples of 20 statin-naïve NST-ACS patients and incubated for 24 hours without and with increasing doses of atorvastatin. Cells were analyzed by flow-cytometry. A. The percentage of CD $4{ }^{+} \mathrm{CD} 28^{\text {null }}$ Tcells producing IFN- $\gamma$ decreased after treatment with atorvastatin $(\mathrm{P}$ for trend $=0.009)$. Data are presented as median and $95 \%$ CI. ${ }^{*} P=0.014$ untreated cells vs $10 \mu \mathrm{g} / \mathrm{mL}$ of atorvastatin; $\uparrow P=0.006$ untreated cells vs $26 \mu \mathrm{g} / \mathrm{mL}$ of atorvastatin. $\mathbf{B}$. The mean fluorescence intensity (MFI) of intracellular IFN- $\gamma$ expression by $\mathrm{CD} 4{ }^{+} \mathrm{CD} 28^{\text {null }} \mathrm{T}-$ cells remained unchanged after atorvastatin treatment $(\mathrm{P}$ for trend $=0.832)$. Data are presented as mean $\pm \mathrm{SD}$. 
hours of incubation), modified the inflammatory activity of T-lymphocytes, although it did not affect their count. Atorvastatin reduced the frequency of $\mathrm{CD} 4^{+} \mathrm{CD} 28^{\text {null }} \mathrm{T}$ cells producing IFN- $\gamma$, while it increased the production of the anti-inflammatory cytokine IL- 10 by $\mathrm{CD} 4{ }^{+} \mathrm{CD} 25^{\text {high }} \mathrm{T}$ cells.

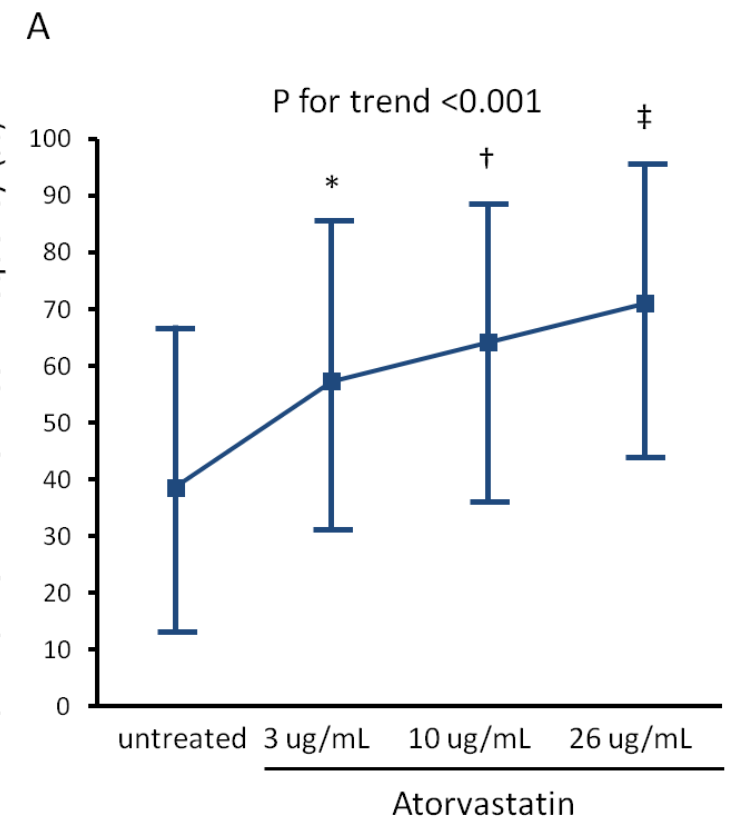

We also explored the mechanisms through which atorvastatin might have immune-suppressive effects in ACS, analyzing the expression of relevant transcription factors and genes related to T-cell functional properties. We found that atorvastatin significantly reduced the expression of the chemokine receptor CCR2, involved

\section{B}

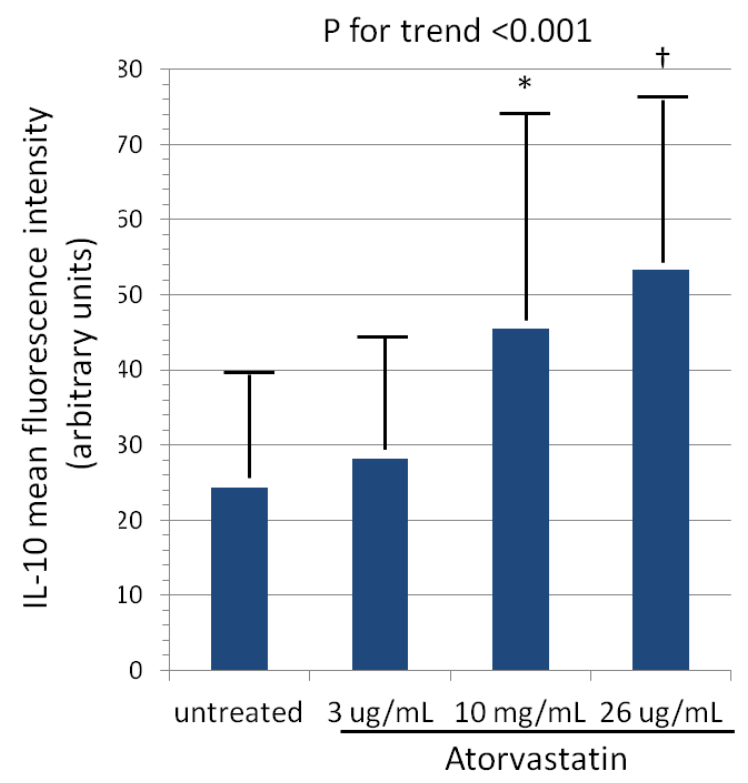

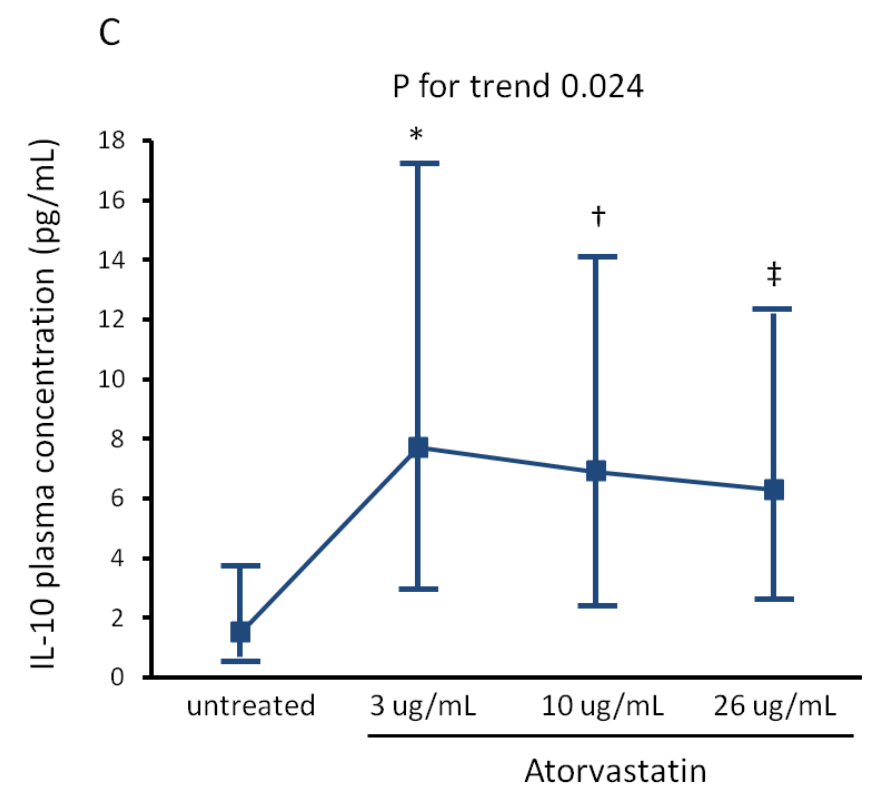

Figure 4: Effects of atorvastatin on $\mathrm{CD}^{+} \mathbf{C D 2 5}{ }^{\text {high }}$ T-cells. Experimental conditions are reported in Figure 3. A. The percentage of $\mathrm{CD} 4{ }^{+} \mathrm{CD} 25^{\text {high }}$ Tcells producing IL-10 increased significantly after treatment with atorvastatin (P for trend $<0.001$ ). Data are presented as median and $95 \%$ CI. ${ }^{*} P=0.034$ untreated cells vs $3 \mu \mathrm{g} / \mathrm{mL}$ of atorvastatin; $\uparrow P=0.022$ untreated cells vs $10 \mu \mathrm{g} / \mathrm{mL}$ of atorvastatin; $\ddagger P<0.001$ untreated cells vs $26 \mu \mathrm{g} / \mathrm{mL}$ of atorvastatin. B. The mean fluorescence intensity (MFI) of intracellular IL-10 expression by $\mathrm{CD} 4{ }^{+} \mathrm{CD} 25^{\text {high }} \mathrm{T}$-cells also increased significantly after atorvastatin treatment $(\mathrm{P}$ for trend $<0.001)$. Data are presented as mean $\pm \mathrm{SD}$. $* P=$ 0.056 untreated cells vs $10 \mu \mathrm{g} / \mathrm{mL}$ of atorvastatin; $\uparrow P<0.001$ untreated cells vs $26 \mu \mathrm{g} / \mathrm{mL}$ of atorvastatin. C. IL- 10 was measured by highsensitivity ELISA in aliquots of $1 \mathrm{~mL}$ of whole blood incubated for 24 hours without and with increasing doses of atorvastatin: 3-10-26 $\mu \mathrm{g} /$ $\mathrm{ml}$. IL-10 concentrations significantly increased after atorvastatin treatment $(\mathrm{P}$ for trend $=0.024) .{ }^{*} P=0.025 \mathrm{untreated}$ cells vs $3 \mu \mathrm{g} / \mathrm{mL}$ of atorvastatin; $\uparrow P=0.016$ untreated cells vs $10 \mu \mathrm{g} / \mathrm{mL}$ of atorvastatin; $₫ P=0.058$ untreated cells vs $26 \mathrm{ug} / \mathrm{mL}$ of atorvastatin. 


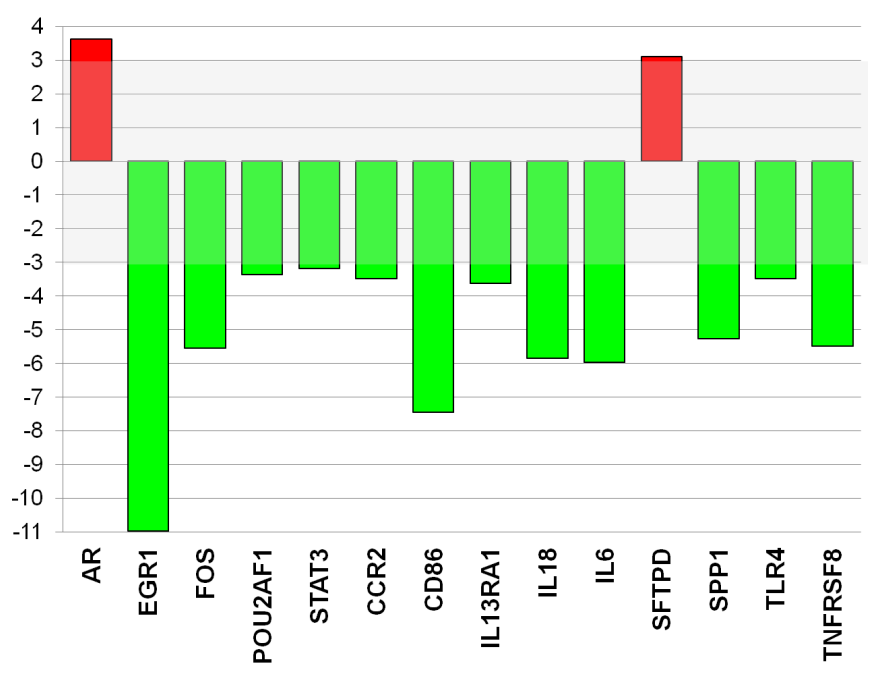

Figure 5: Atorvastatin decreases the expression of inflammatory genes and key transcription factors in $\mathrm{CD}^{+}{ }^{+} \mathrm{T}-\mathrm{cells}$ of patients with ACS. The expression of 84 transcription factors and 84 genes related to both T-effectors and T-regulatory cells was analyzed by quantitative PCR array using a pool of RNA ( $n=20$ patients). Data are presented as fold of regulation by atorvastatin treatment as compared with the gene expression in untreated $\mathrm{CD} 4^{+} \mathrm{T}$-cells. The expression of 2 genes was increased (red) and the expression of 12 genes was reduced (green) ( $>3$ fold changes) by atorvastatin treatment ( $26 \mu \mathrm{g} / \mathrm{ml}$ for 24 hours) compared with control. The complete list of genes investigated by PCR arrays, and changes in their expression induced by atorvastatin, is reported in Tables 2 and 3.

CCR2

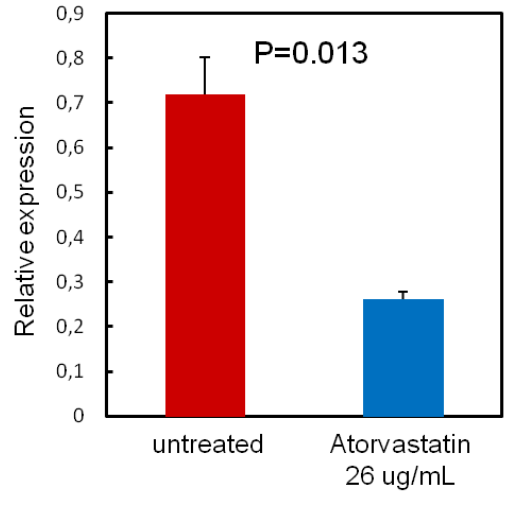

EGR-1

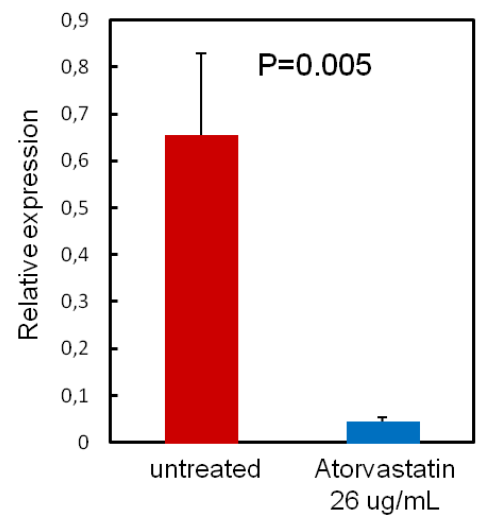

TLR4

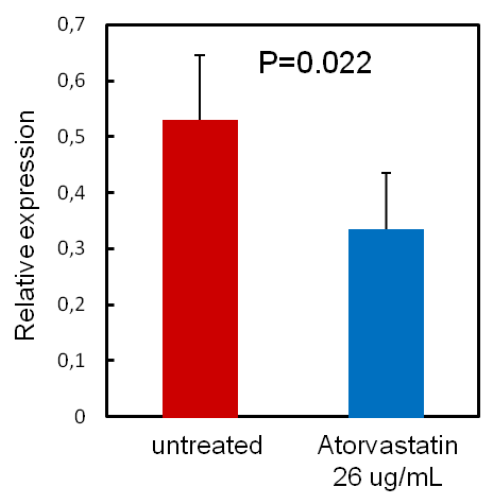

FOS

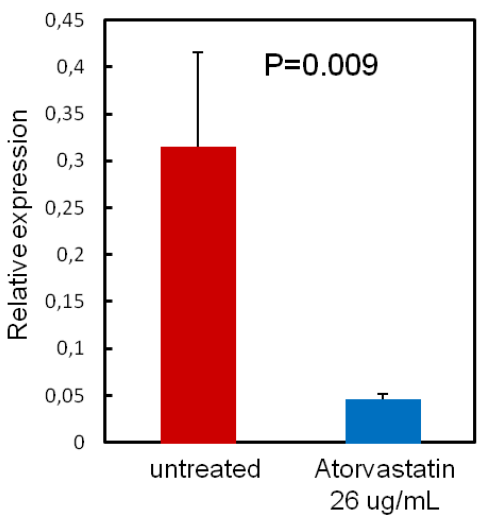

Figure 6: Validation of PCR array results. To validate the PCR array results for selected genes, RT-qPCR was performed using single patients RNA ( $n=20$ patients). Data are presented as relative expression compared to human $\beta-2$-microglobulin ( $\beta-2 \mathrm{MG})$ and glyceraldehyde-3-phosphate dehydrogenase (GAPDH) mRNA levels as endogenous controls, and expressed as mean $\pm \mathrm{SD}$. Atorvastatin treatment ( $26 \mu \mathrm{g} / \mathrm{ml}$ for 24hours) significantly decreases the expression of the transcription factors EGR1 (from $0.65 \pm 0.18$ to $0.04 \pm 0.01 ; P$ $=0.005$ ) and FOS (from $0.31 \pm 0.10$ to $0.05 \pm 0.01 ; P=0.009$ ), Moreover, atorvastatin decreases the expression of the chemokine receptor CCR2 (from $0.72 \pm 0.08$ to $0.26 \pm 0.02 ; P=0.013$ ) and of the pattern recognition receptor TLR4 (from $0.53 \pm 0.12$ to $0.34 \pm 0.10 ; P=0.022$ ). 
in trans-endothelial migration of inflammatory cells, and of TLR4. Both CCR2 and TLR4 induce a series of downstream transcriptional factors, including FOS and EGR1, finally leading to the production of a large number of pro-inflammatory cytokines [22, 23, 24]. Furthermore, EGR1 reduces IL-10 expression at the post-transcriptional level [25].

Finally, we explored the in-vivo effects of atorvastatin, demonstrating that a single high-dose of atorvastatin had also in-vivo early effects on EGR1 mRNA expression and on EGR1 protein levels. Moreover, it reduced the frequency of $\mathrm{CD} 4{ }^{+} \mathrm{CD} 28^{\text {null }} \mathrm{T}$-cells producing IFN- $\gamma$, and increased the production of the antiinflammatory cytokine IL-10 by $\mathrm{CD} 4{ }^{+} \mathrm{CD} 25^{\text {high }} \mathrm{T}$-cells.

\section{Effects of atorvastatin on $\mathrm{CD}^{+}{ }^{+}$-cell functions}

In $\mathrm{ACS}, \mathrm{CD} 4^{+} \mathrm{CD} 28^{\text {null }}$ T-cells are increased in peripheral blood [26] and infiltrate unstable coronary plaques where they undergo clonal expansion [27], probably triggered by specific antigens [28].They produce pro-inflammatory cytokines, in particular IFN- $\gamma$ [26], and express high levels of TRAIL, a member of the TNF family implicated in apoptosis of vascular smooth muscle cells [29]. By directly stimulating apoptosis of vascular smooth muscle cells or by activating macrophages to kill these ones trough IFN- $\gamma$ production, $\mathrm{CD} 4{ }^{+} \mathrm{CD} 28^{\text {null }} \mathrm{T}$-cells could weaken the fibrous cap and destabilize angiogenic vessels, precipitating atherosclerotic plaque rupture [30].
Moreover, these T-cells spontaneously express the subunit $\beta 1$ of the IL-12 receptor even in the absence of antigenic stimulation, and respond to direct IL-12 stimulation with an increased expression of chemokine receptors that promote the tissue homing of effector T-cells [31]. In contrast, the anti-inflammatory cytokine IL-10 contributes to the atheroprotective effects of regulatory T-cells [32], and the expression of regulatory T-cells co-localizes with IL-10 within the atherosclerotic plaques [33]. ACS patients have a skewed helper T-cell differentiation oriented towards the expansion of aggressive effector T-cells and the reduction of Treg number and function [34]. These helper T-cell abnormalities characterize a sizeable proportion of ACS patients [10]. In this subset of ACS patients, the immune response might contribute to plaque destabilization through multiple damaging pathways [35].

Short-term treatment of ACS patients with statins is associated with a reduction of inflammatory markers [36], and with a rapid reduction in the intracellular production of TNF- $\alpha$ and IFN- $\gamma$ by T-cells in-vitro [37]. Rosuvastatin, fluvastatin, and pitavastatin in-vitro treatment inhibits CD4 ${ }^{+}$T-cell-induced endothelial cell apoptosis by suppressing T-cell activation and TRAIL expression upon activation [38]. In two previous observational reports we found that the use of statins was associated with reduced levels of $\mathrm{CD} 4{ }^{+} \mathrm{CD} 28^{\text {null }} \mathrm{T}$ cells $[17,2]$.

Furthermore, short-term treatment of ACS patients with statins is associated with a significant increase of regulatory T-cell inhibitory properties and a significant

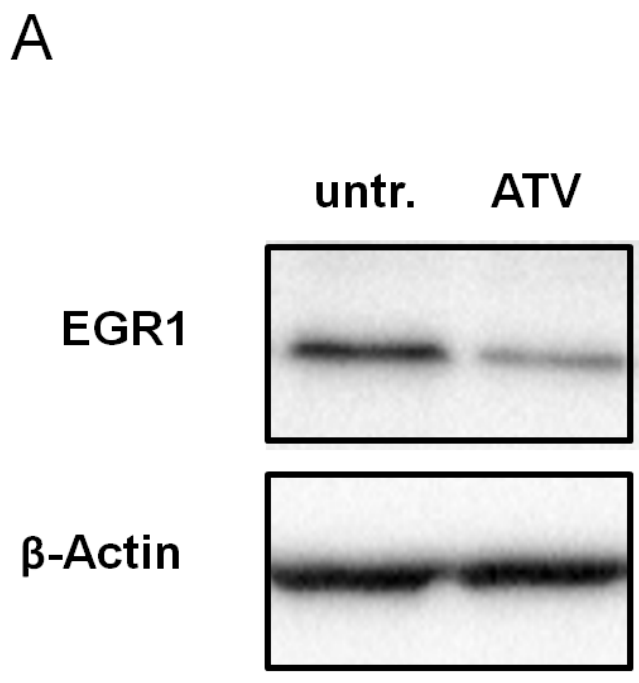

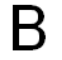

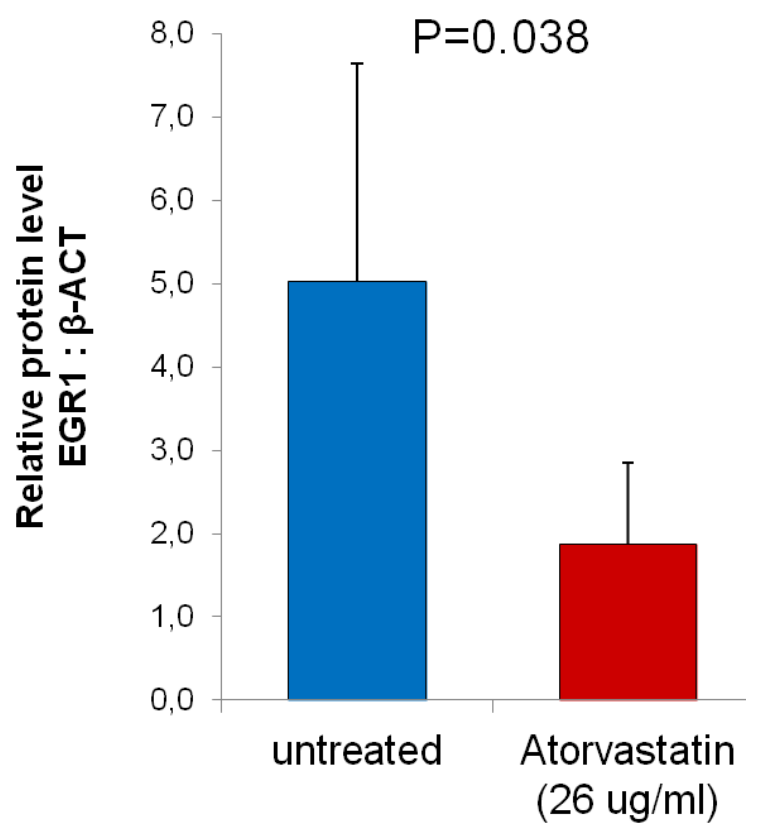

Figure 7: Effect of atorvastatin on EGR-1 protein expression. CD4 ${ }^{+}$T-cells were cultured for 24 hours with (ATV) and without (untr.) atorvastatin $(26 \mu \mathrm{g} / \mathrm{ml})$. Western blot was performed using whole-cell extracts $(25 \mu \mathrm{g}$ per lane $)(n=20$ patients $)$. A. Representative bands for Egr-1 and $\beta$-actin loading controls. B. After atorvastatin treatment, Egr-1 protein decreased significantly. Data are shown as mean \pm S.E.M. 
reduction of serum IFN- $\gamma$ and increase of IL-10 [39, 40]. Statins may enhance regulatory T-cell responses by promoting their chemokine-dependent recruitment into inflammatory sites [21] and/or their differentiation in the periphery [19].

Effects of atorvastatin on the expression of inflammatory genes and transcription factors involved in the immune response

In our study atorvastatin reduced TLR4 gene expression, a pattern-recognition receptor stimulated by several pathogen associated molecular patterns (PAMPs) and damage associated molecular patterns (DAMPs). TLR4 has been found in atherosclerotic lesions and at the site of plaque rupture in patients with MI [41]; its expression is increased in thrombi [42] and in circulating monocytes [43] from patients with ACS. TLR4 stimulation induces intracellular pathways converging on nuclear factor (NF)-kB and mitogen activated protein kinases (MAPK), with subsequent release of pro-inflammatory cytokines and expression of co-stimulatory molecules [23].

Atorvastatin also reduced the expression of the chemokine receptor CCR2, that is involved in $\mathrm{CD}^{+}{ }^{+} \mathrm{T}-$ cell
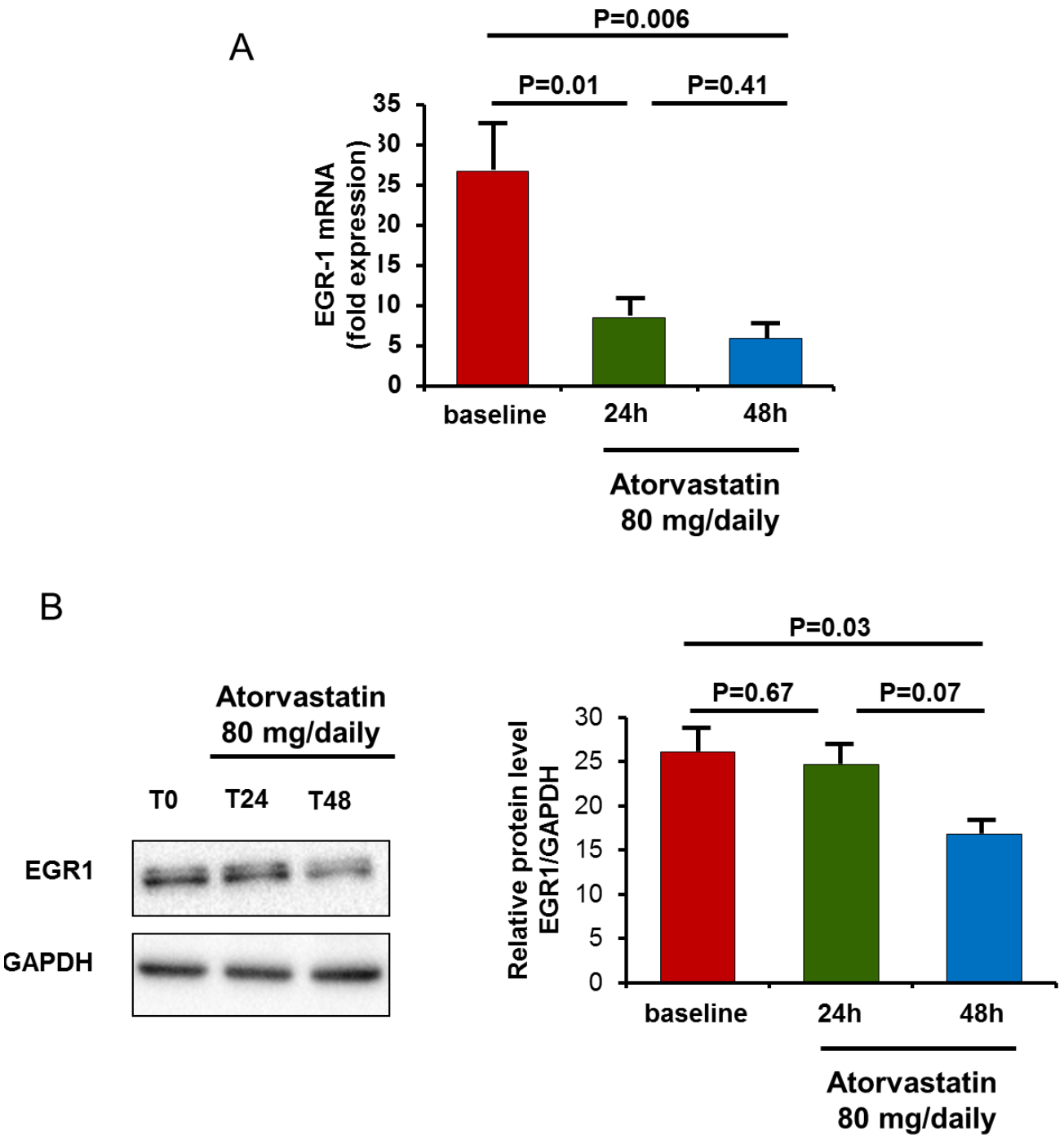

Figure 8: In-vivo effect of atorvastatin on EGR1 gene expression and protein levels. EGR1 gene expression and protein levels were assessed in 10 statin-naïve ACS patients after 24 hours and 48 hours of therapy with atorvastatin ( 80 mg/daily). A. To analyze atorvastatin effects on EGR1 gene expression, RT-qPCR was performed using RNA of each single patient of Cohort 2. Data are presented as relative expression compared to human $\beta$-2-microglobulin $(\beta-2 \mathrm{MG})$ and glyceraldehyde-3-phosphate dehydrogenase (GAPDH) mRNA levels as endogenous controls, and expressed as mean \pm S.E.M. In all patients, EGR1 mRNA levels decreased significantly after 24 hours of atorvastatin therapy. B. To analyze atorvastatin effects on EGR1 protein levels, Western blot was performed using whole-cell extracts (25 $\mu \mathrm{g}$ per lane). Representative bands for EGR11 and GAPDH loading controls are shown. After 48 hours of atorvastatin therapy, EGR1 protein decreased significantly. Data are shown as mean \pm S.E.M. 
transendothelial migration and recruitment at the site of tissue damage and inflammation [23]. CCR2 intracellular pathway also converges on MAPK and, downstream, on the nuclear transcription factors FOS and EGR1, both implicated in the immune response [22]. Indeed, we observed a decrease of the expression of these two transcription factors by atorvastatin. In particular, EGR1 gene showed the highest inhibition (Figure 10).

EGR1 is the prototype of a family of zincfinger transcription factors, "immediate-early response proteins", that is rapidly and transiently induced by a broad spectrum of extracellular signals, including growth factors, cytokines, injurious stimuli and many physiologic stimuli [44]. EGR1 is involved in cell growth, cell differentiation and cell survival [45]. EGR1 is expressed in T-cells and promotes T-cell activation and development by transcriptional induction of key cytokines, such as IL-2 and TNF- $\alpha$, and costimulatory molecules, such as CD40 ligand, after T-cell receptor (TCR) stimulation $[46,22]$. EGR1 also induces the transcriptional activation of T-bet, the master gene regulator of Th1 [47], a T-cell subsets involved in atherosclerosis progression and plaque destabilization [48].

Conversely, EGR1 reduces the expression of IL-10 at post-transcriptional level, by inducing the transcription of a microRNA (hsa-miR-106a) that degrades IL-10 mRNA [25]. EGR1 might also promote atherogenesis

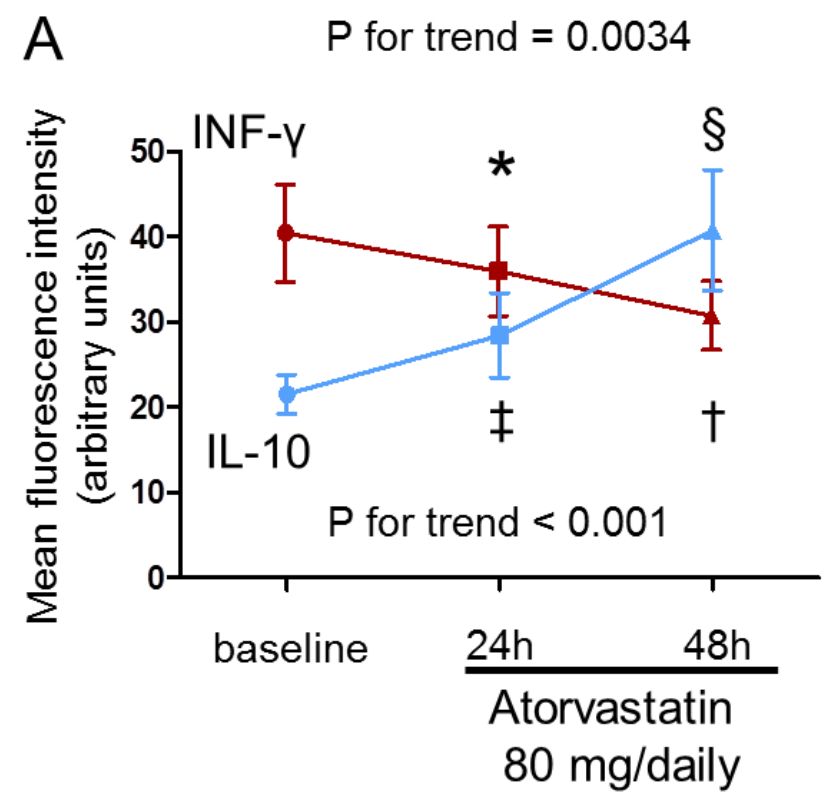

through the activation of inflammatory genes [49, 50]. Thus, we could speculate that, by reducing the expression of the transcription factor EGR1 in CD4+ T-cells, atorvastatin treatment might have the final net effect of reducing pro-inflammatory cytokine secretion, chemokine and chemokine receptor synthesis. This hypothesis is strongly supported by the in-vivo observation that a single high-dose of atorvastatin has early effects on EGR1 mRNA expression and, with a reasonable delay, on EGR1 protein levels. Moreover, it modifies the inflammatory profile of T-lymphocytes by decreasing IFN- $\gamma$ production by aggressive effector T-cells, and increasing the production of the anti-inflammatory cytokine IL-10 by T-cells with a regulatory phenotype (Figure 10).

Although some of these beneficial effects have already been attributed to different statins in humans [51, 52] as well as in animal models [53] and in-vitro [54], our study investigates a comprehensive expression profile in ACS.

In the setting of ACS, it has been proposed that the early outcome improvement observed with intensive statin treatment, compared to a moderate treatment schedule, might be related to anti-inflammatory properties rather than to lipid-lowering effects. According to this, the improvement of short-term outcome associated to intensive statin treatment appeared to correlate with hsCRP level reduction rather than with LDL-cholesterol

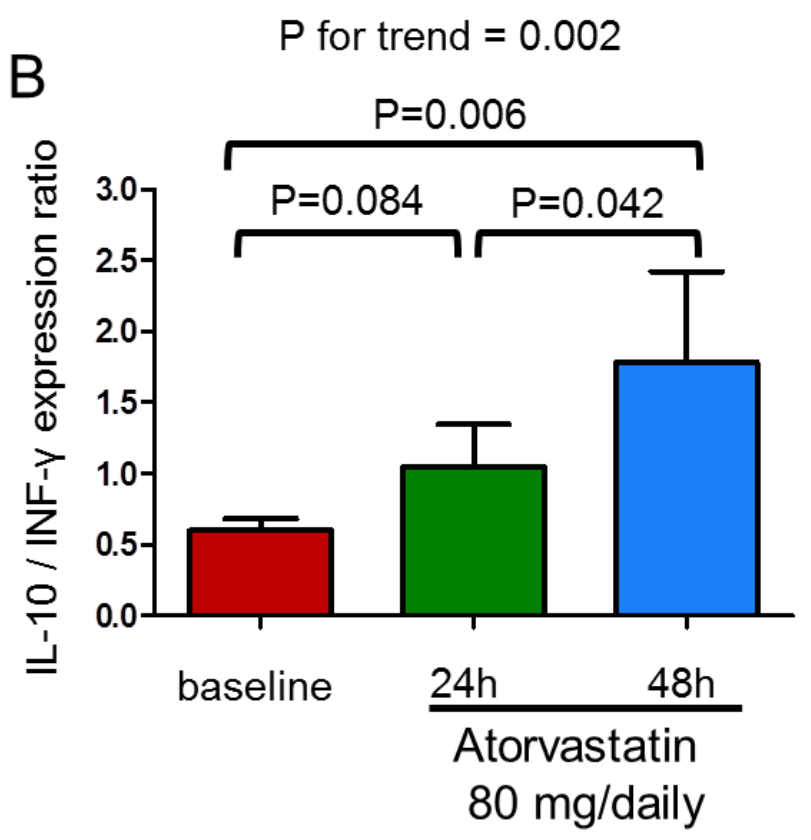

Figure 9: In-vivo effect of atorvastatin on IFN- $\gamma$ production by $\mathrm{CD4}^{+} \mathrm{CD} 28^{\text {null}}$ T-cells and IL-10 production by CD4 $^{+} \mathbf{C D 2 5}^{\text {high }}$ T-cells upon stimulation. IFN- $\gamma$ and IL-10 production were assessed by flow-cytometry in 10 statin-naïve ACS patients after 24 and 48 hours of therapy with atorvastatin $(80 \mathrm{mg} /$ daily). A. The mean fluorescence intensity of intracellular IFN- $\gamma$ expression by $\mathrm{CD} 4{ }^{+} \mathrm{CD} 28^{\text {null }}$ T-cells significantly decreased $(\mathrm{P}$ for trend $=0.0034 ; * P=0.12$, baseline vs 24 hours; $\uparrow P=0.010$, baseline vs 48 hours; $P=$ $0.037,24$ hours vs 48 hours) and the mean fluorescence intensity of intracellular IL-10 expression by CD $4^{+} \mathrm{CD} 25^{\text {high }} \mathrm{T}$-cells significantly increased after 48 hours of atorvastatin therapy ( $\mathrm{P}$ for trend $<0.001 ; \sharp P=0.16$, baseline vs 24 hours; $\S P=0.004$, baseline vs 48 hours; $P$ $=0.006,24$ hours vs 48 hours). Data are shown as mean \pm S.E.M. B. Accordingly, the ratio between IL-10/INF- $\gamma$ expression significantly increased $(\mathrm{P}$ for trend $=0.002)$. Data are shown as mean \pm S.E.M. 
level lowering [55]. However, hs-CRP is more likely a risk marker rather than a causal factor of atherosclerosis [56, 57]. The current data show that atorvastatin acts on the immune-response, offering a causal explanation on why statins ameliorate prognosis in ACS.

\section{CONCLUSIONS}

In ACS, ex-vivo atorvastatin treatment decreases the expression of transcription factors in T-cells, in particular the "immediate-early response protein" EGR1, resulting in inhibition of pro-inflammatory effector T-cells and activation of anti-inflammatory T-cells. EGR1 reduction by atorvastatin has also been confirmed in-vivo, after a single high-dose treatment. Therefore, in the setting of ACS, the early outcome improvement of intensive statin treatment might, at least partially, be related to direct inhibition of the master regulator EGR1 and to consequent immune-suppressive effects.

Some of the pathways inhibited by atorvastatin in the present study have recently been proposed as new therapeutic targets for the prevention of cardiovascular

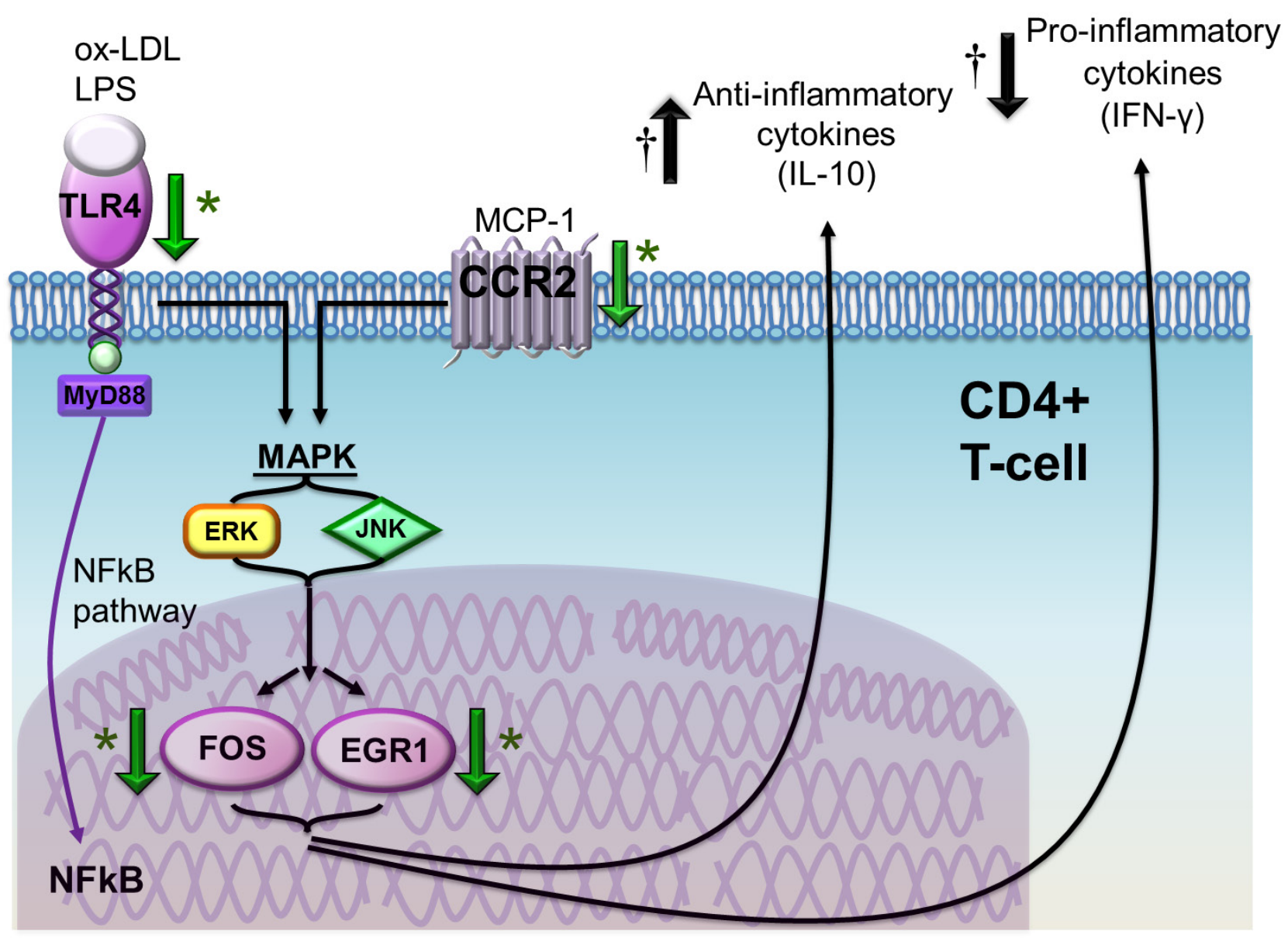

Figure 10: Schematic representation of the effects of atorvastatin on CD4+T-cells in patients with ACS. Atorvastatin decreases toll like receptor (TLR)-4 gene expression, a pattern-recognition receptor stimulated by several pathogen-associated molecular patterns (PAMPs) and damage associated molecular patterns (DAMPs), including bacterial lipolysaccaride (LPS) and ox-LDL, that has been implicated in the initiation and progression of atherosclerosis. TLR-4 stimulation induces intracellular pathways converging on nuclear factor (NF)-kB and mitogen-activated protein kinases (MAPK), with subsequent release of pro-inflammatory cytokines and expression of co-stimulatory molecules. Atorvastatin also reduces the expression of the chemokine (C-C motif) receptor 2 (CCR2), which is the receptor for monocyte chemoattractant protein (MCP)-1 and is involved in $\mathrm{CD} 4{ }^{+} \mathrm{T}$-cell transendothelial migration and recruitment at the site of tissue damage and inflammation. CCR2 intracellular pathway also converges on MAPK pathway, resulting in the activation of ERK and JNK and, eventually, of nuclear transcription factors FBJ murine osteosarcoma viral oncogene homolog (FOS) and early growth response 1 (EGR1), implicated in the immune response. Indeed, we observed an important decrease of EGR1 gene and protein expression by a single high-dose of atorvastatin both ex-vivo and in-vivo, suggesting a specific direct effects of atorvastatin on EGR1. The final net effect is a reduction of pro-inflammatory cytokine secretion and of chemokine and chemokine receptor synthesis, and an increase of anti-inflammatory pathways. *Green arrows indicate the effects of atorvastatin according to molecular assays (reduced expression of the TLR4, CCR2, FOS and EGR1 genes and of EGR1 protein); $\dagger$ black arrows indicate the opposite effects of atorvastatin on IFN- $\gamma$ (reduced intracellular expression by CD4+CD28nullT-cells) and IL-10 (increased intracellular expression by CD4+CD25highT-cells) as assessed by flow-cytometry. 
Table 4: Oligonucleotide primers used for real time quantitative polymerase chain reaction.

\begin{tabular}{|l|l|l|}
\hline $\begin{array}{l}\text { GeneBank accession } \\
\text { number }\end{array}$ & Gene name & Primers 5'-3' \\
\hline NM_001964 & Early growth response (EGR1) & $\begin{array}{l}\text { For GAGCAGCCCTACGAGCAC } \\
\text { Rev GTCTCCACCAGCACCTTCTC }\end{array}$ \\
\hline NM_005252 & $\begin{array}{l}\text { V-fos FBJ murine osteosarcoma viral } \\
\text { oncogene homolog (FOS) }\end{array}$ & $\begin{array}{l}\text { For GACCTTATCTGTGCGTGAA } \\
\text { Rev CACTGGGAACAATACACACT }\end{array}$ \\
\hline NM_001123396 & Chemokine (C-C motif) receptor 2 (CCR2) & $\begin{array}{l}\text { For GCATTCAGCCAGGAGATG } \\
\text { Rev ATCATCGGACTCCACCAA }\end{array}$ \\
\hline NM_138554 & Toll-like receptor 4 (TLR4) & $\begin{array}{l}\text { For GCCCTGCGTGGAGGTGGTT } \\
\text { Rev GGGGAGGTTGTCGGGGATTTTGT }\end{array}$ \\
\hline NM_004048 & $\begin{array}{l}\text { G-2-Microglobulin (B2M) } \\
\text { For AGGACTGGTCTTTCTATCTCTTGT } \\
\text { Rev ACCTCCATGATGCTGCTTACA }\end{array}$ \\
\hline NM_002046 & $\begin{array}{l}\text { Glyceraldehyde-3-phosphate dehydrogenase } \\
\text { (GAPDH) }\end{array}$ & $\begin{array}{l}\text { For AGTCAGCCGCATCTTCTT } \\
\text { Rev GCCCAATACGACCAAATCC }\end{array}$ \\
\hline
\end{tabular}

Confirmation and validation of candidate genes among those reduced or increased by atorvastatin was performed by real time quantitative polymerase chain reaction (RT-qPCR) after reverse transcription of single-patient RNA.

diseases. This is the case for the MCP-1/CCR2 pathway [58], the TLR4 pathway [59], and for a newly identified microRNA that functions as a negative regulator on inflammatory cytokines TNF- $\alpha$ and IL-6 via targeting EGR1 in vivo [60].

\section{MATERIALS AND METHODS}

\section{Study population}

We prospectively evaluated 334 consecutive patients admitted to our CCU from June 2011 to June 2013 with a diagnosis of NSTE-ACS. We enrolled 40 patients (Cohort 1) who had never received statin treatment and with circulating $\mathrm{CD} 4{ }^{+} \mathrm{CD} 28^{\text {null }}$ T-cell frequency $>4 \%$, as our group has previously shown that $\mathrm{CD} 4{ }^{+} \mathrm{CD} 28^{\text {null }} \mathrm{T}$-cell frequency $>4 \%$ predicts recurrence of acute coronary events [2]. Ten additional patients (Cohort 2) were enrolled from November 2013 to May 2014 using the same inclusion criteria, to analyze the in-vivo effects of atorvastatin on EGR1 gene expression and protein levels.

Exclusion criteria were: 1) age $>80$ years; 2) evidence of inflammatory or infectious diseases, malignancies, immunologic or hematological disorders; 3 ) diabetes mellitus; 4) ejection fraction $<40 \%$; 5) treatment with anti-inflammatory drugs other than low-dose aspirin.

The study was approved by the local ethics committee and appropriate consent was obtained from study patients.

\section{Screening for $\mathrm{CD}^{+} \mathrm{CD28}{ }^{\text {null }} \mathrm{T}-$ cell frequency}

Immediately after CCU admission, $1 \mathrm{ml}$ of whole blood anti-coagulated with EDTA was used to assess $\mathrm{CD} 4^{+} \mathrm{CD} 28^{\text {null }} \mathrm{T}-$ cell frequency by flow cytometry, using
anti-CD4 fluorescin-isothiocyanate (FITC) conjugated and anti-CD28 phycoerythrin-Cy5 (PE-Cy5) conjugated monoclonal antibodies (all Beckman Coulter, Brea, CA). After the initial screening, venous peripheral blood samples were obtained from patients with circulating CD $4^{+} \mathrm{CD} 28^{\text {null }}$ T-cell frequency $>4 \%$.

\section{Isolation of $\mathrm{CD4}^{+} \mathrm{T}$-cells and atorvastatin treatment}

Peripheral blood mononuclear cells (PBMCs) were obtained from whole blood samples by standard gradient centrifugation over Ficoll-Hypaque (GE Healthcare BioSciences, Piscataway, NJ). CD4 ${ }^{+}$T-cells were isolated by magnetic micro-beads (CD4+T-cell isolation kit MACS, Miltenyi Biotec, Auburn, CA) according to the manufacturer's instructions. Pure atorvastatin, kindly provided by Pfizer (New York, NY), was dissolved in 2\% dimethilsulfoxide (DMSO) solution at final concentration of $50 \mathrm{mM}$. CD4 $4^{+}$-cells were incubated for 24 hours, under sterile conditions at $37^{\circ} \mathrm{C}$ in an atmosphere containing $5 \%$ $\mathrm{CO} 2$, at a density of $1 \times 10^{6} / \mathrm{ml}$ in RPMI 1640 medium (Sigma, St. Louis, MO) supplemented with 10\% fetal bovin serum (Invitrogen, Carlsbad, CA) with and without increasing doses of atorvastatin: 3-10-26 $\mu \mathrm{g} / \mathrm{ml}$. These doses were chosen on the basis of the observation that comparable plasmatic concentrations correspond to in vivo doses of 10-40-80 $\mathrm{mg}$ of atorvastatin [61].

\section{T-cell analysis by flow cytometry}

In Cohort 1 patients, phenotypic and functional characteristics of $\mathrm{CD}^{+}$T-cells treated/untreated with atorvastatin were assessed by flow-cytometry using fluorochrome-conjugated monoclonal anti-human antibody $(\mathrm{mAb})$, including isotype controls. Flow- 
cytometry quantization was performed on 40.000 live cells. Data acquisition was performed using a FC500 Flow Cytometry System (Beckman Coulter, Brea, CA) and data analysis using the $\mathrm{Kaluza}^{\circledR}$ analysis software packages (Beckman Coulter, Brea, CA).

We assessed total CD4+, CD4+CD28null, CD4+CD25high, CD4+CD25highFoxp3+T-cells. We also determined IFN $-\gamma$ production by CD4+CD28nullT-cells and IL-10 production by CD4+CD25highT-cells upon stimulation.

$\mathrm{CD} 4^{+} \mathrm{CD} 28^{\text {null }}$ T-cell frequency was determined using anti-CD4-fluorescinisothiocyanate (FITC)conjugated $\mathrm{mAb}$ and anti-CD28-phycoerythrin-Cy5(PECy5)-conjugated mAb (both Beckman Coulter, Brea, CA). The percentage of $\mathrm{CD} 4^{+} \mathrm{CD} 28^{\text {null }} \mathrm{T}$-cells was expressed as percentage of the entire population of $\mathrm{CD}^{+} \mathrm{T}$-cells.

$\mathrm{CD} 4{ }^{+} \mathrm{CD} 25^{\text {high }}$ T-cell frequency was obtained using monoclonal anti-CD4-FITC-labeled and monoclonal anti-human CD25-APC-labeled, on the basis of high CD25-APC fluorescence in comparison with intermediate CD25-APC fluorescence in $\mathrm{CD}^{+} \mathrm{CD} 25^{+} \mathrm{T}$-cells. After cell surface staining, cell fixation and permeabilization, cells were stained with the intracellular PE-conjugated anti-Foxp3 mAB (eBioscience, San Diego, CA). The percentage of $\mathrm{CD} 4{ }^{+} \mathrm{CD} 25^{\text {high }} \mathrm{T}$-cells and of $\mathrm{CD} 4{ }^{+} \mathrm{CD} 25^{\text {high }} \mathrm{T}-$ cells expressing Foxp ${ }^{+}$T-cells was then calculated as percentage of $\mathrm{CD} 4{ }^{+} \mathrm{CD} 25^{+} \mathrm{T}$-cell population.

In order to evaluate T-cell function, we determined IFN- $\gamma$ production by $\mathrm{CD} 4{ }^{+} \mathrm{CD} 28^{\text {null }}$ T-cells and IL-10 production by $\mathrm{CD} 4^{+} \mathrm{CD} 25^{\text {high }} \mathrm{T}$-cells upon stimulation. In the assessment of IL-10 production, regulatory T-cells were identified as $\mathrm{CD} 4{ }^{+} \mathrm{CD} 25^{\text {high }} \mathrm{T}$-cells, in order to avoid a stressful cell-handling as required to perform permeabilization for intra-cytoplamasmatic and intranuclear protein assessment, potentially resulting in a less accurate measurement of IL-10. A significant correlation was observed between $\mathrm{CD} 4{ }^{+} \mathrm{CD} 25^{\text {high }} \mathrm{T}$-cells and $\mathrm{CD}^{+} \mathrm{CD} 25^{\text {high }}$ Foxp3 $3^{+}$T-cells $(\mathrm{R}=0.67 ; P<0.001)$. Briefly, cytokines production by $\mathrm{CD} 4^{+} \mathrm{T}$-cell subsets was assessed after 4-hours in vitro activation with $100 \mathrm{ng} / \mathrm{ml}$ phorbol-2-myristate-13-acetate (PMA) (Sigma, St. Louis, MO) and $1 \mu \mathrm{g} / \mathrm{ml}$ ionomycin (Sigma, St. Louis, MO). Cells were incubated in polypropylene tubes at $37^{\circ} \mathrm{C}$ for a total of $4 \mathrm{hrs}$; during the last $2 \mathrm{hrs}, 10 \mu \mathrm{g} / \mathrm{mL}$ Brefeldin A (Sigma, St. Louis, MO) was added to block extracellular secretion of cytokines. After cell surface staining, cell fixation was done with IC FIX Buffer (eBioscience, San Diego, CA) for $15 \mathrm{~min}$ at $4^{\circ} \mathrm{C}$. Cell membranes were reversibly permeabilized with Permeabilization Buffer (eBioscience, San Diego, CA) and intracellular cytokines were labeled with mouse anti-human IFN- $\gamma$ PE-conjugated (eBioscience, San Diego, CA) and mouse anti-human IL-10 Peridinin-Chlorophyll-Protein-Complex (PerCP)-conjugated (R\&D Systems, Minneapolis, MN). In addition, IFN- $\gamma$ and IL-10 intracellular expression was presented as MFI.

\section{Cytokine measurements}

In the same patients of Cohort 1, citrate whole-blood samples were collected from an antecubital vein at the time of patient enrollment. Immediately after sampling, aliquots of $1 \mathrm{~mL}$ of whole blood were incubated for 24 hours under sterile conditions at $37^{\circ} \mathrm{C}$ in an atmosphere containing 5\% CO2 without and with increasing doses of atorvastatin: 3, 10, $26 \mu \mathrm{g} / \mathrm{ml}$. Afterwards, plasma samples were obtained, stored at $-80^{\circ} \mathrm{C}$ and analysed in a single bath at the end of the study. Plasma levels of IL-10 and IFN- $\gamma$ were measured with high-sensitivity ELISA kits (human-IL-10, Aushon Biosystems, Billerica, MA; human-IFN- $\gamma$, Bender MedSystem, Vienna, Austria), according to the manufacturer's instructions. The linear range of detection was 0.78 to $200 \mathrm{pg} / \mathrm{ml}$ for IL-10 and 1.6 to $100 \mathrm{pg} / \mathrm{ml}$ for IFN- $\gamma$. All samples were measured in duplicate, and the intra- and inter-assay variability was $<10 \%$.

\section{RNA preparation and quantitative PCR array analysis}

Patients in Cohort 1 underwent quantitative PCR array. CD4 ${ }^{+}$T-cells were incubated for 24 hours without and with $26 \mu \mathrm{g} / \mathrm{ml}$ of atorvastatin (see above). Total RNA was isolated by using RNeasy minikit (Qiagen, Valencia, CA) from $3 \times 10^{6} \mathrm{CD} 4^{+} \mathrm{T}$-cells per patient. RNA was quantified using a Picodrop spectrophotometer measuring the absorbance at 260/280 nm, and RNA integrity was confirmed with the Agilent Bioanalyzer (Agilent Technologies, Santa Clara CA). For each condition (untreated/treated with atorvastatin) a pool of RNA was constituted, starting with the same amount of RNA (500 ng) from each patient.

Array targets were prepared from $435 \mathrm{ng}$ of total RNA from each pool (untreated/treated with atorvastatin) using SABiosciences Kit for genomic DNA removal and reverse transcription, and two focused panels of genes were analyze by quantitative PCR array $\left(\mathrm{RT}^{2}\right.$ Profiler ${ }^{\mathrm{TM}}$ PCR Array, SABiosciences, Frederick, MD, USA). We performed the Human Transcription Factors RT $^{2}$ Profiler ${ }^{\mathrm{TM}}$ PCR Array (Catalog \#PAHS-075) and the Human Th1-Th2-Th3 RT2 Profiler ${ }^{\text {TM }}$ PCR Array (Catalog \#PAHS-034) both profiling the expression of 84 genes, according to the manufacturer's instruction. Thermal cycling parameters were $95^{\circ} \mathrm{C}$ for $10 \mathrm{~min}$, followed by 40 cycles of amplifications at $95^{\circ} \mathrm{C}$ for $15 \mathrm{~s}, 55^{\circ} \mathrm{C}$ for $30 \mathrm{~s}$, $72^{\circ} \mathrm{C}$ for $30 \mathrm{~s}$, and $72^{\circ} \mathrm{C}$ for $5 \mathrm{~min}$ as the final elongation step performed on IQ5 Icycler (BioRad). Relative levels of mRNA expression were normalized in all samples with the expression levels of housekeeping genes, and data analysis was done using the Web portal (http:// www.sabiosciences.com/pcr/arrayanalysis.php). The relative expression of each gene was compared with the 
expression in the control group and calculated using the $\Delta \triangle \mathrm{CT}$ method. Each reported value represented the mean decrease (or increase) of mRNA expression relative to the control levels. A P-value of $\leq 0.05$ and a fold change in gene expression of $>3$ were taken as significant.

\section{Quantitative real-time RT-PCR}

Confirmation and validation of candidate genes was performed by real time quantitative polymerase chain reaction (RT-qPCR) after reverse transcription of RNA obtained from each single patient of Cohort 1 using the iScript $^{\mathrm{TM}}$ cDNA Synthesis Kit (BioRad Laboratories, Hercules, CA). For each patient $250 \mathrm{ng}$ of RNA from $\mathrm{CD}^{+} \mathrm{T}$-cells untreated/treated with atorvastatin was used to synthesize cDNA in a final volume of $20 \mu \mathrm{l} .1$ $\mu l$ of cDNA was used as template for RT-qPCR in a 15 $\mu 1$ reaction mixture, including $\mathrm{SsoAdvanced}^{\mathrm{TM}} \mathrm{SYBR}^{\circledR}$ Green supermix (BioRad) and $400 \mathrm{~nm}$ of each primer. Oligonucleotide primers for RT-qPCR were designed with Beacon Design (Table 4). RT-qPCR was performed on triplicates samples using the IQ5 Icycler (BioRad). After initial denaturation step of $30 \mathrm{sec}$ at $95^{\circ} \mathrm{C}$, a twosteps cycling procedure (denaturation at $95^{\circ} \mathrm{C}$ for $5 \mathrm{sec}$, annealing and extension at $64^{\circ} \mathrm{C}$ for $30 \mathrm{sec}$ ) was performed for 40 cycles and followed by melting curve at $95^{\circ} \mathrm{C}$ for $6 \mathrm{sec}$. Data are normalized to human $\beta$-2-microglobulin $(\beta-2 \mathrm{MG})$ and glyceraldehyde-3-phosphate dehydrogenase (GAPDH) mRNA levels as an endogenous control and are expressed relative to control sample using the formula $2^{-\Delta \Delta \mathrm{CT}}$, where $\mathrm{C}_{\mathrm{T}}$ is the threshold cycle number.

Also, the in-vivo effect of atorvastatin on EGR1 gene expression was assessed by RT-qPCR.

\section{Western-blot assays}

We also explored whether atorvastatin treatment might influence protein expression levels of EGR1, both ex-vivo and in-vivo. Western-blot analysis was carried out in CD4 $4^{+}$T-cells $\left(1 \times 10^{6}\right)$ cultured for 24 hours with and without $26 \mu \mathrm{g} / \mathrm{ml}$ atorvastatin. Western blot was performed using whole-cell extracts (25 $\mu \mathrm{g}$ per lane). Protein were resolved on 7\% SDS-PAGE gels and transferred to nitrocellulose membranes. Membranes were blocked with 5\% non-fat milk in phosphate buffered saline and 1\% Tween-20 (TBS) and labeled with primary antibodies (all from Santa Cruz Biotechnology, Dallas, $\mathrm{Tx}$ ): mouse monoclonal $\mathrm{IgG}_{1}$ anti-human $\beta$-actin (sc130301) and rabbit polyclonal IgG anti-human EGR1 p82 (588, sc-110). To saving samples, materials, and time we stripped and re-probed a single membrane for multiple targets instead of running and blotting multiple gels. Membranes were stripped with a buffer consisting of $\beta$-mercaptoethanol, SDS, and Tris- $\mathrm{HCl}$ and re-probed with the specific antibodies. Then, specific bands were detected by a chemiluminescent system (ChemiDoc MP System, Biorad) using corresponding secondary antibodies conjugated with horseradish peroxidase.

Also, the in-vivo effect of atorvastatin on EGR1 protein expression was assessed by western-blot.

\section{In-vivo effects of atorvastatin}

In-vivo effects of atorvastatin on EGR1 gene expression and protein levels were analyzed in Cohort 2 patients treated with atorvastatin $80 \mathrm{mg} /$ daily, at 24 hours and 48 hours of treatment, by RT-qPCR and by westernblotting, respectively (see above).

We also determined the in-vivo effects of atorvastatin on IFN- $\gamma$ production by CD4+CD28nullT-cells and IL-10 production by CD4+CD25highT-cells upon stimulation by flow cytometry (see above).

\section{Statistical analysis}

No power calculation could be performed because of lack of previous studies in this setting. Thus, the enrollment of 40 patients in Cohort 1 and of 10 patients in Cohort 2 was arbitrary.

The percentage of T-cell subsets along with cytokine production by these T-cells, were not normally distributed; they were expressed as median and range and analyzed using the Friedman's two-way analysis of variance by ranks for multiple pairwise comparisons with Dunnet's correction. The remaining continuous variables, including gene and protein expression were normally distributed; they were expressed as mean $\pm \mathrm{SD}$ and were compared using 1-way ANOVA for repeated measures with the Bonferroni correction for multiple pairwise comparisons or using the paired t-test, as appropriate. Proportions were compared using the Chi square test.

Univariate logistic regression analysis was applied to individuate the variables associated with the effects of atorvastatin (a reduction of $\mathrm{CD} 4{ }^{+} \mathrm{CD} 28^{\text {null }} \mathrm{T}$-cells producing IFN $\gamma$ and/or an increase of $\mathrm{CD} 4{ }^{+} \mathrm{CD} 25^{\text {high }} \mathrm{T}$-cells producing IL-10 higher than $50 \%$ after incubation with atorvastatin $26 \mu \mathrm{g} / \mathrm{ml})$. The following clinical and laboratory variables were tested: age, sex, classical risk factors, previous history of acute coronary events, left ventricular ejection fraction, multi-vessel disease, troponin $\mathrm{T}$ levels, lipid profile (total-cholesterol, LDL-cholesterol, and HDLcholesterol). At univariate logistic regression analysis none of the variables considered, including lipid profile, demonstrated any association with effects of atorvastatin. Therefore, the multivariate analysis was not performed.

A two-tailed $P$ value $<0.05$ was considered statistically significant. Statistical analysis was performed with SPSS 18.0 software (SPSS Inc., Chicago, Illinois). 


\section{Abbreviations}

INF- $\gamma=$ Interferon $-\gamma$

ACS $=$ Acute Coronary Syndromes

IL-10 = Interleukin-10

NSTE $=$ Non-ST Elevation

EGR1 $=$ Early Growth Response 1

TLR4 $=$ Toll-like Receptor-4

CCR2 $=$ Chemokine (C-C motif) Receptor-2

PAMPs $=$ Pathogen Associated Molecular Patterns

DAMPs $=$ Damage Associated Molecular Patterns

TCR $=$ T-cell Receptor

NF-kB $=$ Nuclear Factor-kB

\section{ACKNOWLEDGMENTS}

The authors would like to thank the Coronary Care Unit staff of the "Policlinico A.Gemelli", Catholic University of the Sacred Heart for its invaluable help, support and patience.

\section{CONFLICTS OF INTEREST}

None to declare.

\section{SOURCES OF FUNDING}

This work was supported by an unrestricted grant of Pfizer (New York, NY) and partially by "Ministero dell'Istruzione dell'Università e della Ricerca Scientifica" [progetto strategico di ricerca finalizzata 2010: "Caratterizzazione del profilo protrombotico ed infiammatorio/immunitario di pazienti con sindrome coronarica acuta a differente rischio, con approccio genomico e proteomico"].

\section{DISCLOSURES}

This work was supported by an unrestricted grant of Pfizer (New York, NY).

\section{Author contributions}

Dr. Giovanna Liuzzo, Dr. Anna Severino and Dr. Chiara Zara have conceived and designed the study and contributed to data interpretation.

Dr. Liuzzo and Dr. Daniela Pedicino have drafted the manuscript.

Dr. Simona Giubilato, Dr. Vincenzo Pazzano, Dr. Ada F. Giglio, Dr. Francesco Trotta, Dr. Claudia Lucci, Dr. Antonio Iaconelli, Dr. Aureliano Ruggio have crucially participated in data collection and analysis of patients with acute coronary syndromes.
Dr. Chiara Zara, Dr. Mara Campioni, Dr. Davide Flego and Dr. Giulia Angelini have collected and analyzed all the biological parameters, including T-cell analysis by flow-cytometry, cytokine measurements, and quantitative PCR array analysis.

Dr. Giovanna Liuzzo, Dr. Luigi Marzio Biasucci and Dr. Filippo Crea have revised critically the manuscript for important intellectual content.

Dr. Filippo Crea has also given the final approval of the manuscript submitted.

\section{REFERENCES}

1. Hansson GK. Inflammation, atherosclerosis, and coronary artery disease. N Engl J Med. 2005; 352:1685-1695. doi: 10.1056/NEJMra043430.

2. Liuzzo G, Biasucci LM, Trotta G, Brugaletta S, Pinnelli M, Digianuario G, Rizzello V, Rebuzzi AG, Rumi C, Maseri A, Crea F. Unusual CD4+ CD28null T lymphocytes and recurrence of acute coronary events. J Am CollCardiol. 2007; 50:1450-1458. doi:10.1016/j.jacc.2007.06.040.

3. Giubilato S, Liuzzo G, Brugaletta S, Pitocco D, Graziani F, Smaldone C, Montone RA, Pazzano V, Pedicino D, Biasucci LM, Ghirlanda G, Crea F. Expansion of CD4+CD28null $\mathrm{T}$ lymphocytes in diabetic patients: exploring new pathogenetic mechanisms of increased cardiovascular risk in diabetes mellitus. Eur Heart J. 2011; 32:1214-1226. doi:10.1093/eurheartj/ehq499.

4. Sakaguchi S, Miyara M, Costantino CM, Hafler DA. FOXP3 + regulatory $\mathrm{T}$ cells in the human immune system. Nature Rev Immunol. 2010; 10:490-500. doi:10.1038/ nri2785.

5. Brusko TM, Putnam AL, Bluestone JA. Human regulatory $T$ cells: role in autoimmune disease and therapeutic opportunities. Immunol Rev. 2008; 223:371-390. doi: 10.1111/j.1600-065X.2008.00637.x.

6. Flego D, Severino A, Trotta F, Previtero M, Ucci S, Zara C, Massaro G, Pedicino D, Biasucci LM, Liuzzo G, Crea F. Increased PTPN22 expression and defective CREB activation impair regulatory T-cell differentiation in non-ST-segment elevation acute coronary syndromes. J Am Coll Cardiol. 2015; 65:1175-1186. doi: 10.1016/j. jacc.2015.01.027.

7. Mor A, Luboshits G, Planer D, Keren G, George J. Altered status of CD4(+) CD25(+) regulatory $\mathrm{T}$ cells in patients with acute coronary syndromes. Eur Heart J. 2006; 27:25302537. doi:10. 1093/eurheartj/ehl222.

8. Chalikias GK, Tziakas DN, Kaski JC, Kekes A, Hatzinikolaou EI, Stakos DA, Tentes IK, Kortsaris AX, Hatseras DI. Interleukin-18/interleukin-10 ratio is an independent predictor of recurrent coronary events during a 1-year follow-up in patients with acute coronary syndrome. Int J Cardiol. 2007; 117:333-339. doi:10.1016/j. ijcard.2006.05.017. 
9. Mälarstig A, Eriksson P, Hamsten A, Lindahl B, Wallentin L, Siegbahn A. Raised interleukin-10 is an indicator of poor outcome and enhanced systemic inflammation in patients with acute coronary syndrome. Heart. 2008; 94:724-729. doi:10.1136/hrt.2007.119271.

10. Liuzzo G, Montone RA, Gabriele M, Pedicino D, Giglio AF, Trotta F, Galiffa VA, Previtero M, Severino A, Biasucci LM, Crea F. Identification of unique adaptive immune system signature in acute coronary syndromes. Int J Cardiol. 2013; 168:564-567. doi:10.1016/j.ijcard.2013.01.009.

11. Morrow DA, de Lemos JA, Sabatine MS, Wiviott SD, Blazing MA, Shui A, Rifai N, Califf RM, Braunwald E. Clinical relevance of C-reactive protein during follow-up of patients with acute coronary syndromes in the Aggrastat-toZocor Trial. Circulation. 2006; 114:281-288. doi: 10.1161/ CIRCULATIONAHA.106.628909.

12. Nissen SE, Tuzcu EM, Schoenhagen P, Crowe T, Sasiela WJ, Tsai J, Orazem J, Magorien RD, O’Shaughnessy C, Ganz P. Reversal of Atherosclerosis with Aggressive Lipid Lowering (REVERSAL) Investigators. Statin therapy, LDL cholesterol, C-reactive protein, and coronary artery disease. N Engl J Med. 2005; 352:29-38. doi: 10.1056/ NEJMoa042000.

13. Ridker PM, Cannon CP, Morrow D, Rifai N, Rose LM, McCabe CH, Pfeffer MA, Braunwald E. Pravastatin or Atorvastatin Evaluation and Infection TherapyThrombolysis in Myocardial Infarction 22 (PROVE ITTIMI 22) Investigators. C-reactive protein levels and outcomes after statin therapy. N Engl J Med. 2005; 352:2028 doi: 10.1056/NEJMoa042378.

14. Blanco-Colio LM, Muñoz-García B, Martín-Ventura JL, Lorz C, Díaz C, Hernández G, Egido J. 3-Hydroxy-3Methylglutaryl Coenzyme A reductase inhibitors decrease Fas ligand expression and cytotoxicity in activated human $\mathrm{T}$ lymphocytes. Circulation. 2003; 108:1506-1513. doi:10.1161/01.CIR.0000089086.48617.2B.

15. Dunn SE, Youssef S, Goldstein MJ, Prod'homme T, Weber MS, Zamvil SS, Steinman L. Isoprenoids determine Th1/ Th2 fate in pathogenic $T$ cells, providing a mechanism of modulation of autoimmunity by atorvastatin. J Exp Med. 2006; 203:401-412 doi: 10.1084/jem.20051129.

16. Youssef S, Stüve O, Patarroyo JC, Ruiz PJ, Radosevich JL, Hur EM, Bravo M, Mitchell DJ, Sobel RA, Steinman L, Zamvil SS. The HMG-CoA reductase inhibitor, atorvastatin, promotes a Th2 bias and reverses paralysis in central nervous system autoimmune disease. Nature. 2002; 420:78-84.

17. Brugaletta S, Biasucci L M, Pinnelli M, Biondi-Zoccai G, Di Giannuario G, Trotta G, Liuzzo G, Crea F. Novel antiinflammatory effect of statins: reduction of CD4+CD28null $\mathrm{T}$ lymphocyte frequency in patients with unstable angina. Heart. 2006; 92:249-250. doi:10.1136/hrt.2004.052282.

18. Link A, Selejan S, Hewera L, Walter F, Nickenig G, Böhm M. Rosuvastatin induces apoptosis in CD4+CD28null T cells in patients with acute coronary syndromes. Clin Res
Cardiol. 2011; 100:147-158. doi: 10.1007/s00392-0100225-8

19. Kim YC, Kim KK, Shevach EM. Simvastatin induces Foxp $3+\mathrm{T}$ regulatory cells by modulation of transforming growth factor-beta signal transduction. Immunology. 2010; 130:484-493. doi:10.1111/j.1365-2567.2010.03269.x.

20. Mausner-Fainberg K1, Luboshits G, Mor A, MayselAuslender S, Rubinstein A, Keren G, George J. The effect of HMG-CoA reductase inhibitors on naturally occurring CD4+CD25+ T cells. Atherosclerosis. 2007; 197:829-839. doi:10.1016/j.atherosclerosis. 2007. 07.031.

21. Mira E, León B, Barber DF, Jiménez-Baranda S, Goya I, Almonacid L, Márquez G, Zaballos A, Martínez-A C, Stein JV, Ardavín C, Mañes S. Statins induce regulatory T cell recruitment via a CCL1 dependent pathway. J Immunol. 2008; 181:3524-3534. doi: 10.4049/jimmunol.181.5.3524.

22. Gómez-Martín D, Díaz-Zamudio M, Galindo-Campos M, Alcocer-Varela J. Early growth response transcription factors and the modulation of immune response: implications towards autoimmunity. Autoimmun Rev. 2010; 9:454-58. doi:10.1016/j.autrev.2009.12.006.

23. Kawai T, Akira $\mathrm{S}$. The role of pattern-recognition receptors in innate immunity: update on Toll-like receptors. Nat Immunol. 2010; 11:373-384. doi:10.1038/ni.1863.

24. Kolattukudy PE, Niu J. Inflammation, Endoplasmic Reticulum Stress, Autophagy, and the Monocyte Chemoattractant Protein-1/CCR2 Pathway. Circ Res. 2012; 110:174-89. doi: 10.1161/CIRCRESAHA.111.243212.

25. Sharma A, Kumar M, Aich J, Hariharan M, Brahmachari SK, Agrawal A, Ghosh B. Posttranscriptional regulation of interleukin-10 expression by hsa-miR-106a. Proc Natl AcadSci U S A. 2009; 106:5761-5766. doi: 10.1073/ pnas.0808743106.

26. Liuzzo G, Kopecky SL, Frye RL, O'Fallon WM, Maseri A, Goronzy JJ, Weyand CM. Perturbation of the T-cell repertoire in patients with unstable angina. Circulation. 1999; 100:2135-9. doi: 10.1161/01.CIR.100.21.2135.

27. Liuzzo G, Goronzy JJ, Yang H, Kopecky SL, Holmes DR, Frye RL, Weyand CM. Monoclonal T cell proliferation and plaque instability in acute coronary syndromes. Circulation. 2000; 101:2883-2888. doi:10.1161/01.CIR.101.25.2883.

28. Zal B, Kaski JC, Arno G, Akiyu JP, Xu Q, Cole D, Whelan M, Russell N, Madrigal JA, Dodi IA, Baboonian C. Heat-shock protein 60-reactive CD4+CD28null $\mathrm{T}$ cells in patients with acute coronary syndromes. Circulation. 2004; 109:1230-1235.doi: 10.1161/01. CIR.0000118476.29352.2A.

29. Sato K, Niessner A, Kopecky SL, Frye RL, Goronzy JJ, Weyand CM. TRAIL-expressing T cells induce apoptosis of vascular smooth muscle cells in the atherosclerotic plaque. $\mathrm{J}$ Exp Med. 2006; 203:239-250. doi: 10.1084/jem.20051062.

30. Dumitriu IE, Araguas ET, Baboonian C, Kaski JC. CD4+ CD28 null T cells in coronary artery disease: when helpers become killers. Cardiovasc Res. 2009; 81:11-19. doi: 
$10.1093 / \mathrm{cvr} /$.

31. Zhang X, Niessner A, Nakajima TMa-Krupa W, Kopecky SL, Frye RL, Goronzy JJ, Weyand CM. Interleukin 12 induces T-cell recruitment into the atherosclerotic plaque. Circ Res. 2006; 98:524-31. doi: 10.1161/01. RES.0000204452.46568.5.

32. Ait-Oufella H, Salomon BL, Potteaux S, Robertson AK, Gourdy P, Zoll J, Merval R, Esposito B, Cohen JL, Fisson S, Flavell RA, Hansson GK, Klatzmann D, Tedgui A, Mallat Z. Natural regulatory $T$ cells control the development of atherosclerosis in mice. Nat Med. 2006; 12:178-180. doi: $10.1038 / \mathrm{nm} 1343$

33. Heller EA, Liu E, Tager AM, Yuan Q, Lin AY, Ahluwalia N, Jones K, Koehn SL, Lok VM, Aikawa E, Moore KJ, Luster AD, Gerszten RE. Chemokine CXCL10 promotes atherogenesis by modulating the local balance of effector and regulatory T cells. Circulation. 2006; 113:2301-2312. doi: 10.1161/CIRCULATIONAHA.105.605121.

34. Caligiuri G, Nicoletti A. Lymphocyte responses in acute coronary syndromes: lack of regulation spawns deviant behavior. Eur Heart J. 2006; 27:2485-2486. doi: http:// dx.doi.org/10.1093/eurheartj/ehl284.

35. Crea F, Liuzzo G. Pathogenesis of acute coronary syndromes. J Am CollCardiol. 2013. 61:1-11. doi:10.1016/j. jacc.2012.07. 064.

36. Kinlay S, Schwartz GG, Olsson AG, Rifai N, Leslie SJ, Sasiela WJ, Szarek M, Libby P, Ganz P. Myocardial Ischemia Reduction with Aggressive Cholesterol Lowering Study Investigators. High-dose atorvastatin enhances the decline in inflammatory markers in patients with acute coronary syndromes in the MIRACL study. Circulation. 2003; 108:1560-1566. doi: 10.1161/01. CIR.0000091404.09558.AF.

37. Link A, Ayadhi T, Böhm M, Nickenig G. Rapid immunomodulation by rosuvastatin in patients with acute coronary syndrome. Eur Heart J. 2006; 27:2945-2955. doi: http://dx.doi.org/10.1093/eurheartj/ehl277.

38. Sato K, Nuki T, Gomita K, Weyand CM, Hagiwara N. Statins reduce endothelial cell apoptosis via inhibition of TRAIL expression on activated CD4 T cells in acute coronary syndrome. Atherosclerosis. 2010; 213:33-39. doi: 10.1016/j.atherosclerosis.

39. Hu Z, Li D, Hu Y, Yang K. Changes of CD4+CD25+ regulatory $\mathrm{T}$ cells in patients with acute coronary syndrome and the effects of atorvastatin. J Huazhong Univ Sci Technolog Med Sci. 2007; 27:524-527. Doi:10.1007/ s11596-007-0512-4.

40. Li JJ, Li YS, Fang CH, Hui RT, Yang YJ, Cheng JL, Gao RL. Effects of simvastatin within two weeks on antiinflammatory cytokine interleukin 10 in patients with unstable angina. Heart. 2006; 92:529-30. doi:10.1136/hrt. 2004.057489.

41. Ishikawa Y, Satoh M, Itoh T, Minami Y, Takahashi Y, Akamura M. Local expression of toll-like receptor 4 at the site of ruptured plaques in patients with acute myocardial infarction. Clin Sci. 2008; 115:133-140. doi:10.1042/ CS20070379.

42. Spanaus KS, Yonekawa K, Wischnewsky MB, Corti R, Kucher N, Roffi M, Eberli FR, Amann-Vesti B, Gay S, von Eckardstein A, Lüscher TF, Maier W. Cellular actors, Tolllike receptors, and local cytokine profile in acute coronary syndromes. Eur Heart J. 2010; 31:1457-1469. doi: 10.1093/ eurheartj/ehq084.

43. Methe H, Kim JO, Kofler S, Weis M, Nabauer M, Koglin J. Expansion of circulating Tol-like receptor 4-positive monocytes in patients with acute coronary syndrome. Circulation. 2005; 111:2654-61. doi: 10.1161/ CIRCULATIONAHA.104.498865.

44. Thiel G, Cibelli G. Regulation of life and death by the zinc finger transcription factor Egr-1.J Cell Physiol. 2002; 193:287-292. doi: 10.1002/jcp.10178.

45. Dias $\mathrm{S}, \mathrm{Xu} \mathrm{W}$, McGregor S, Kee B. Transcriptional regulation of lymphocyte development. CurrOpin Genet Dev. 2008; 18:441-448. doi: 10.3390/biom5021020.

46. Bettini M, Xi H, Milbrandt J, Kersh GJ. Thymocyte development in early growth response gene 1-deficient mice. J Immunol. 2002; 169:1713-1720. doi: 10.4049/ jimmunol.169.4.1713.

47. Shin HJ, Lee JB, Park SH, Chang J, Lee CW. T-bet expression is regulated by EGR1-mediated signaling in activated T cells. Clinical immunology. 2009; 131: 285394. doi:10.1016/j.clim.2009.02.009.

48. Methe H, Brunner S, Wiegand D, Nabauer M, Koglin J, Edelman ER. Enhanced T-helper-1 lymphocyte activation patterns in acute coronary syndromes. 2005; 45:1939-1945. doi:10.1016/j.jacc.2005.03.040.

49. Harja E, Bucciarelli LG, Lu Y, Stern DM, Zou YS, Schmidt AM, Yan SF. Early growth response-1 promotes atherogenesis: mice deficient in early growth response-1 and apolipoprotein E display decreased atherosclerosis and vascular inflammation. Circ Res. 2004; 94: 333-339. doi: 10.1161/01.RES.0000112405.61577.95.

50. Khachigian LM. Early growth response-1 in cardiovascular pathobiology. Circ Res. 2006; 98:186-191. doi: 10.1161/01. RES.0000200177.53882.c3.

51. Niessner A, Steiner S, Pleiner J, Seidinger D, Maurer G, Goronzy JJ, Weyand CM, Kopp CW, Huber K, Wolzt M, Wojta J. Simvastatin suppresses endotoxininduced upregulation of toll-like receptors 4 and 2 in vivo. Atherosclerosis. 2006; 189:408-413. doi:10.1016/j. atherosclerosis.2005.12.022.

52. Zhang X, Jin J, Peng X, Ramgolam VS, Markovic-Plese S. Simvastatin inhibits IL-17 secretion by targeting multiple IL-17-regulatory cytokines and by inhibiting the expression of IL-17 transcription factor RORC in CD4+ lymphocytes. J Immunol. 2008; 180:6988-9696. doi: 10.4049/jimmunol.180.10.6988.

53. Bea F, Blessing E, Shelley MI, Shultz JM, Rosenfeld 
ME. Simvastatin inhibits expression of tissue factor in advanced atherosclerotic lesions of apolipoprotein E deficient mice independently of lipid lowering: potential role of simvastatin-mediated inhibition of Egr-1 expression and activation. Atherosclerosis. 2003; 167:187-194. doi:10.1016/S0021-9150(02)00387-8.

54. Lamon BD, Summers BD, Gotto AM Jr, Hajjar DP. (2009) Pitavastatin suppresses mitogen activated protein kinasemediated Erg-1 induction in human vascular smooth muscle cells. Eur J Pharmacol. 606:72-76. doi: 10.1016/j. ejphar.2008.12.047.

55. Nissen SE. High-dose statins in acute coronary syndromes: not just lipid levels. JAMA. 2004; 292:1365-1367. doi:10.1001/jama.292.11.1365.

56. Libby P, Crea F. Clinical implications of inflammation for cardiovascular primary prevention. Eur Heart J. 2010; 31:777-783. doi: 10.1093/eurheartj/ehq022.

57. Zacho J, Tybjærg-Hansen A, Jensen JS, Grande P, Sillesen H, Nordestgaard BG. Genetically elevated C-reactive protein and ischemic vascular disease. N Engl J Med. 2008; 359:1897-1908. doi:10.1038/nature01158.

58. Gilbert J, Lekstrom-Himes J, Donaldson D, Lee Y, Hu M, Xu J, Wyant T, Davidson M; MLN1202 Study Group. Effect of CC chemokine receptor 2 CCR2 blockade on serum C-reactive protein in individuals at atherosclerotic risk and with a single nucleotide polymorphism of the monocyte chemoattractant protein-1 promoter region. Am J Cardiol. 2011; 107:906 -911. doi: 10.1016/j. amjcard.2010.11.005.
59. Stoll LL, Denning GM, Weintraub NL. Endotoxin, TLR4 signaling and vascular inflammation: potential therapeutic targets in cardiovascular disease. Curr Pharm Des. 2006; 12:4229-4245. doi: http://dx.doi. org/10.2174/138161206778743501.

60. Zhang J, Xie S, Ma W, Teng Y, Tian Y, Huang X, Zhang Y. A newly identified microRNA, mmu-miR-7578, functions as a negative regulator on inflammatory cytokines tumor necrosis factor- $\alpha$ and interleukin- 6 via targeting Egr1 in vivo. J Biol Chem. 2013; 288:4310-4320. doi: 10.1074/jbc. M112.351197.

61. Shitara Y, Sugiyama Y. Pharmacokinetic and pharmacodynamic alterations of 3-hydroxy-3methylglutaryl coenzyme A (HMG-CoA) reductase inhibitors: Drug-drug interactions and interindividual differences in transporter and metabolic enzyme functions. Pharmacology \& Therapeutics. 2006; 112:71-105. doi:10.1016/j.pharmthera.2006.03.003. 